\title{
BİST 100 Endeksinin Spektral Analiz Yöntemiyle İncelenmesi
}

\author{
Selim BEKÇİOĞLU * \\ Yusuf KADERLI ** \\ Batu VARLIK ${ }^{* * *}$
}

\section{ÖZET}

Finansal piyasaların döngüsel özellikleri, gelişmiş piyasalarda pek çok defa incelenmiştir. Bugüne kadar, İstanbul Menkul Kıymetler Borsası'nın döngüsel karakterlerini inceleyen bir çalışma olmamakla beraber, Borsa İstanbul'un yeni bir borsa olmasl, yeterli derinliğe sahip olmamast, dolayısıyla belli zaman aralığındaki veriye dayalı olarak yapılacak bu tür zaman serileri analizlerini de zorlaştırmıştır. İstanbul Borsası'nın 1988 yılından itibaren kayıt edilen borsa endeksi, 1995 yılından itibaren zaman serileri ile analiz edilebilecek derinliğe ulaşmıştır. Yüksek matematik bilgisi gerektiren spektral analiz, döngüsel olayların frekans bileşenlerine ayrıştırlarak incelenmesini sağlar. Dolayısıyla bu çalışmada, öncelikle zaman serileri ve klasik spektral analiz teorisi açılklamıştır. Finans ile ilgili bir alandaki çalışmay yapmada en sağlıklı yöntem, incelenen verinin üzerine oturduğu sistemin temellerini ve geçmişini göstermektir. Bu nedenle, Türkiye'nin borsa ile ilgili geçmişi kısaca rakamlarla verilmiştir. Daha sonra, Borsa İstanbul Ulusal 100 Endeksi'nin 19952015 yılları aralığındaki verileri klasik spektral analiz tekniği kullanılarak analiz edilmiştir.

Anahtar Kelimeler: BISTT 100, Borsa İstanbul, Ulusal 100 Endeksi, Zaman Serileri, Fourier Dönüşümü, Spektral Analiz.

JEL Sinıflandırması: C32, C58, E32, G17.

\section{Spectral Analysis of Istanbul Stock Exchange ISE-100 Index}

\section{ABSTRACT}

Cyclical characteristics of financial markets have been analyzed many times. However, the cyclical features of Istanbul Stock Exchange have not been analyzed till today. Being a new stock market and not having enough depth, caused ISE not to have enough time series data and therefore obstruct applying any times series analysis to Istanbul Stock Exchange. The indices of ISE have been recorded since 1988, and it has attained to a point where any time series analysis can be applied. Spectral analysis technique, which requires high mathematics knowledge, analyzes cyclical events by decomposing its periodic components. Therefore, in this study, time series and classical spectral analysis theory has been explained primarily. Since understanding foundations of analyzed issue strengthen the study, history and basics of ISE have been expressed later. Finally, the ISE 1995-2015 data has been analyzed with classical spectral technique.

Keywords: ISE, Istanbul Stock Exchange, BIST100, XU100, Time Series, Spectral Analysis, Fourier Transformations

Jel Classification: C32, C58, E32, G17.

\footnotetext{
* Prof. Dr. Selim Bekçioğlu, Adnan Menderes Üniversitesi, Nazilli İktisadî ve İdari Bilimler Fakültesi, sbekcioglu@adu.edu.tr

** Prof. Dr. Yusuf Kaderli, Adnan Menderes Üniversitesi, Nazilli İktisadî ve İdari Bilimler Fakültesi, y.kaderli@yahoo.com

*** Dr. Batu Varlık, Adnan Menderes Üniversitesi, Nazilli İktisadî ve İdari Bilimler Fakültesi, bvarlik@gmail.com
} 


\section{GíRiş}

Kişiler ve kurumlar elde ettikleri gelirin bir kısmını tüketirler ve geri kalanını tasarruf ederler. Tasarruflar reel ve finansal yatırımlara dönüştürülür. Reel yatırımlar gerçek olan ve arzulanan yatırımlardır. Reel yatırımlar katma değer, istihdam, büyüme ve refah sağlar. Ancak, tasarruflar menkul kıymetler, emtia, gayrimenkul, kıymetli taşlar, yağlı boya tablolar ve benzeri gibi çok çeşitli araçlara da yatırılabilir. Özellikle, tasarrufların menkul kıymetlere yatırılması, dolaylı olarak reel yatırımların yapılmasına yardımcı olur. Menkul kıymet yatırımları, ilgili menkul kıymete ait nakit akışlarının miktarını, zamanlamasını ve riskliliği göz önüne alarak, onun şimdiki değerini hesaplarlar. Bulunan değer, ilgili menkul kıymetin içsel (intrinsic) değeridir. Eğer hesaplanan içsel değer ilgili menkul kıymetin piyasa (borsa) değerinden yüksek ise, o menkul kıymet yatırım yapılabilir niteliktedir. Menkul kıymet piyasalarının etkin olduğu piyasalarda içsel değer ile piyasa değeri birbirine yakın olacaktır. Aksi bir durum piyasadaki yatırımcıları harekete geçirecek, bu iki değer eşit oluncaya kadar alım satım işlemleri sürecektir. Etkin piyasaların mevcut olduğu bir durumda, yatırımcıların fiyatları öngörerek ek kârlar sağlaması oldukça zor olacaktır. Ancak, piyasaların etkinliği kavramı, gün geçtikçe önem kazanan davranışsal finans taraftarları tarafından sorgulanmaktadır. Davranışsal finans teorisi, yatırımcıların rasyonel olmadığını, geçmiş hisse senedi fiyatlarının gelecek menkul kıymet fiyat değişimlerini öngörmek için kullanılabileceğini ve menkul kıymet fiyat trendlerini analiz ederek, mali tabloları inceleyerek yatırımcıların yüksek getiri sağlayabileceklerini savunmaktadır (Bekçioğlu, 1983: 5-20).

$\mathrm{Bu}$ makalenin amacı, davranışsal finans teorisinin sorgulamaları 1şı ̆̆ 1 altında, oluşan değişik periyotlu dalgalanmaların gerekçelerini de açıklayarak, spektral analiz yöntemiyle BİST 100 Endeksini incelemektir. Bu amaç doğrultusunda, kullanılan metodoloji, incelemeye konu olan veri hakkında bilgi verildikten sonra, spektral analiz teorik olarak açıklanacak ve bu yöntem ülkemiz borsasına uygulanacak ve elde edilen bulgular yorumlanacak ve önerilerde bulunulacaktır.

\section{SPEKTRAL ANALIZ}

\subsection{Zaman Serileri ve Dalgalanmalar}

Dünya, zamanla değişen pek çok olayı içerir. Bu olayların bazı özelliklerini ölçen veriler, artan zamana göre dizildiklerinde zaman serilerini oluştururlar. Trend ve mevsimsel hareketlerle çalışmalar, Durbin-Watson istatistikleri, birinci dereceden serisel korelasyon gibi uygulamalar, yetmişli yıllardan sonrası, ekonometrik uygulamalarda önemli bir yer edinmiştir (Granger ve Watson, 1984: 980). Ekonomik, sosyal, psikolojik vb. gibi çeşitli nedenlerin, zamanla ilişkili değişkenler üzerindeki etkisi, yön ve şiddetinin farklı olması nedeniyle, zaman serisi gözlem değerlerinde bazı değişmeler gözlenir. Zaman serileri, bu değişmeler nedeniyle çözümlenmeden bir anlam ifade etmezler. Zaman serileriyle kurulacak ve spektral analiz tekniği gibi tekniker kullanılarak kurulacak matematiksel modellerle, serileri etkileyen bileşenlerin etkilerinin tahmin edilmesi ve hesaplanan tahminlerden yararlanarak, serilenin gelecek dönemlerine ilişkin öngörü de yapılabilir. Zaman serilerinin uzun dönem eğilimine trend; mevsimin zaman serileri üzerindeki etkilerine, mevsimlik dalgalanmalar; ekonominin gelen durumu ile ilgili etkilere, konjonktür dalgalanmalar ve doğal, ekonomik veya siyasi nedenlerden ortaya çıkan ve ne zaman meydana geleceği belli olmayan tesadüfi hareketlere de, rastgele dalgalanmalar adı verilir. Bu yöntemde, zaman serisinin herhangi bir $t$ anındaki değerinin, bu dört unsurun çarpımından ileri geldiği varsayılır. İlk üç unsur zaman serisinin 
sistematik bileşenlerini, sonuncusu ise, sistematik olmayan tesadüfi kısmı oluşturur (Özoğuz, 1986: 86).

Ancak, serinin dört unsurdan meydana gelmesi, bunların birbirinden bağımsız faktörlerin etkisi altında oluştuğu anlamını taşımaz. Zaman serisi unsurları birbirlerine bağlı ve karşılıklı ilişki içindedirler. Bu nedenle, seriyi - birbirinden bağımsız etkilerini tespit içinunsurlara ayırma yöntemi (Time Series Decomposition Method), aslında yapay bir varsayıma dayanmaktadır. Bununla birlikte, özellikle tahmin işlemlerindeki sakıncasına rağmen, model yine de, zaman serileri analizinde en yaygın yaklaşımdır.

Trend bileşeni, zaman bağlı değişken üzerindeki genel eğilime neden olan uzun dönemli etkileri açıklar. $\mathrm{Bu}$ özellikler genellikle, demografik özelliklerdeki, coğrafi dağılımdaki kişi başına gelirdeki, teknolojik gelişmelerdeki ve fiyat değişmelerindeki etkiler olarak suralanabilir. Ekonomik verilerde trend; ortalamada, varyansta ve bir bileşenin önemindeki değişim veya otoregresif değişimdeki trend olarak ayrılabilir. Eğer seriler sürekli artan bir değer üzerinde salınım yapıyorsa, bu ortalamada bir trend olduğunu gösterir. Eğer serilerdeki salınımlar bir ortalama etrafında zamanla değişiyorsa, bu da varyanstaki trendi ifade eder. Nüfus artışı, üretim, tüketim gibi verilerde genellikle ortalamada trend bulunurken, fiyat verileri, endeks gibi verilerin varyansinda trend bulunabilir. Ancak, bu trendler birbirinden bağımsız değillerdir ve birbirlerini etkilemektedirler.

Mevsimlik dalgalanmalar, mevsimin zaman serileri üzerindeki etkilerini ifade etmektedir ve birbirini izleyen yılların, mevsimlerin, çeyrek yılların, ayların, ya da günlerin aynı zaman noktalarında zaman serisi gözlem değerlerindeki bir artma veya bir azalma şeklindeki düzenli değişmeleri açıklar. Mevsimsel değişmeler genellikle iklimle, saatle, ya da geleneklerle ilişkilidir ve dolayısıyla dalgalanmalar şeklide olurlar, dalga boyu (frekansı) ve dalga yüksekliği olan periyodik ve döngüsel özelliğe sahiptirler. Zaman serilerinde mevsimsel dalgalanmaların incelenmesi, kısa dönem dalgaların anlaşılması ve açıklanması, kısa dönem tahminlerin yapilabilmesi ve son olarak da zaman serilerinden mevsim etkilerinin arındırılması açısından önemlidir (Kazan ve Altan, 2002: 1-10). Ancak, "p" periyodu ile salınan fonksiyon, $p, p / 2, p / 3, \ldots v b$. periyoda sahip sinüzoidallerden oluşmaktadır. Dolayısıyla, bir serinin mevsimsel bileşenini Fourier dönüşümü yardımıyla periyodogram analizi veya spektral analizle incelemek istediğimizde 12 aylık periyodu yanında 3 ve 2,4 aylık periyotlar da özel bir öneme sahiptir. Mevsimsel dalgalanmalar zamanla değişmiyorsa, tavsiye edilen yöntem 12 aylık ve bunun harmoniklerini kullanan Fourier terimlerini kullanmaktır. Eğer bileşen zamanla değişiyorsa bu durumda karmaşık demodülasyon tekniğini kullanmak daha faydalı olacaktır (Granger ve Hatanaka, 1964: 14-15).

Konjonktür dalgalanmalar ise, ekonominin gelen durumu ile ilgili dalgalanmalardır. Ekonomik durumun durgunluk, yükseliş, refah ve gerileme gösterdiği dalgalanmalar konjonktür dalgalanmalardır. Ekonomi, iş idaresi, iklim değişimi, moda alanlarıyla ilgili etkiler nedeniyle trend düzeyi etrafında iki ile on yıl ya da daha fazla zaman aralıklarıyla, herhangi bir dönemde, artma veya azalma şeklinde tekrarlanabilen, periyodik olmayan ancak döngüsel değişmelerdir. Bu değişmeler, ekonomi ve iş idaresiyle ilgili değiş̧kenler üzerinde aynı şiddette olmasa da aynı yönde etki ederler. Konjonktürün artma yönündeki etkisi, trendin artış eğilimini hızlandırır. Buna karş1lık, konjonktürün azalma yönündeki etkisi trendin artış hızını yavaşlatır, hatta tamamen durdurabilir. Ancak, konjonktür dalgalanmalar refahı ve gerilemeyi temsil etmelerine rağmen, bu hareketlerin aynı periyot ve genliklerde periyodik 
olarak tekrar tekrar oluştuğuna dair ciddi bir kanıt yoktur. (Gordon, 1961: 250). Bazı döngüler hafif bazıları şiddetlidir, bazıları kısa sürer bazıları uzun sürer. Bu düzensizlik nedeniyle ekonomik model oluşturmadaki zorluk, serilerin istatistiki olarak analizini de zorlaştırmaktadır. Araştırmacılar farklı konjonktür döngüsel salınımları incelemişlerdir. Bunlar; 40-60 yıl arası döngülü Kontratieff Uzun Dalgas1, 20 yıllık Kuznets Uzun Dalgas1, 15-20 yıl arası döngülü İnşaat Döngüsü, 6-11 yıl arası döngülü büyük (majör) döngü ile 2-4 yıl arası döngülü küçük (minör) döngü, 1-11 yıl arası döngülü iktisadî döngüler ve ortalama süreleri 24 ay olan Mack'ın Alt döngüleri olarak sayılabilir (Granger ve Hatanaka, 1964: 1617).

Düzenliliğin ve aynı zamanda düzensizliğin bileşimi olan ekonomik zaman serileri ekonometrik modellerin oluşturulmasında ve analiz edilmesindeki en önemli engeldir. Spektral teknik kullanılarak tüm bu salınımlar sinüzoidallere çevrilerek, bu düzenli ve düzensiz zaman serilerine matematiksel olarak doğal bir yaklaşım yapılır. Spektral teknik, sinüsler toplamı yerine frekans bandındaki sinüslerin integralini alarak özellikle iktisadî dalgalanmaları daha etkin olarak açıklar. Bu özellik, spektral analizin Fourier analizine göre önemli üstünlüklerinden biridir. Ancak, spektral analizde ihtiyaç duyulan veri süresi, dalga boyunun yedi katı olması, konjonktür dalgalanmaların analizinde yeterli uzunlukta verinin elde bulunamamasına neden olur. $\mathrm{Bu}$ durum da sağlıklı analizin yapılmasını engeller. Örneğin, Kuznets Uzun Dalgası'nın analizi için 140 yıllık veriye gereksinim vardır. Ayrıca, yedi katsayısı serilerin ortalamasında bir trendin olmadığı durumlar için geçerlidir; ortalamada trendin olduğu serilerde bu süre daha da uzun olacaktır.

Rastgele dalgalanmalar ise, doğal, ekonomik veya siyasi nedenlerden ortaya çıkan ve ne zaman meydana geleceği belli olmayan tesadüfi hareketlerdir. Beklenmedik olayların zaman serileri üzerindeki etkisiyle meydana gelmektedir. Rastgele serilerin üç aydan daha fazla sürmeyeceği varsayılır.

\subsection{Spektral Analiz Teorisi}

Zaman serilerini analiz etmenin önemli araçlarından biri, olayların yoğunluğunu ve değişkenliğini frekansa veya periyotlarına göre gösteren güç spektrumunu kullanmaktır. $\mathrm{Bu}$ süreç, en basit anlamda otokovaryans fonksiyonunun Fourier dönüşümü olarak gösterilebilir. Güç spektrumu serilerdeki ardışık bağımlılığı göstermede ve döngüsel (periyodik) olaylar ile bunlara ait modellerin ortaya konmasında faydalı bir araç olarak kullanılmaktadır (Brillinger, 2001: 15724-15731).

Spektral yöntemler, hisse senetlerinin analizinde de konjonktür, mevsimsel ve daha kısa periyotlardaki döngüsel etkilerin incelenmesinde kullanılır. Bu şekilde, zamanın fonksiyonu olan hisse senedi fiyatları frekans ortamına dönüştürülür ve zaman serilerini kullanan istatistik fonksiyonlarının analiz edemediği konjonktür ve mevsimsel etkiler belirlenir (Wold, 1967: 288-293). Zaman serilerinin spektral ayrıştırması, spektral yoğunluk fonksiyonunun oluşmasını sağlar ve her frekans bandının zaman serilerinin varyansına olan göreli etkisini ölçer. Aslında, spektral analiz, zaman serilerin varyansının frekans bileşenlerine göre incelenmesidir (Leuthold, 1972: 879-889). Ancak, spektral analizin yapılabilmesi için eldeki zaman serilerinin durağan olması gerekmektedir. Durağanlık, klasik spektral analiz tekniğinin temel koşuludur. Durağanlık ortalamasıyla, varyans ve ortak varyansı zaman içinde değişmeyen ve iki dönem arasındaki ortak varyansın bu ortak 
varyansın hesaplandığı döneme değil de yalnızca iki dönem arasındaki uzaklığa bağlı olan olasılıklı bir süreçtir (Gujarati, 2001: 713). Durağanlık, serilerin sabit bir ortalamaya, sabit bir varyansa ve gecikme seviyesine bağlı bir kovaryansa sahip olmasını ifade eden bir kavramdır. Durağanlı, zaman serisi verilerinin sabit ortalama, sabit varyans ve seriye ait iki değer arasındaki farkın zamana değil, yalnızca iki zaman değeri arasındaki farka bağlı olması şeklinde ifade edilir.

Zaman serilerinin durağan olmaması durumunda, zaman serileri trend içerecektir. $\mathrm{Bu}$ durumda zaman serileri, durağanlaştırıldıktan sonra spektral teknikle analiz edilmelidir. Zaman serileri durağan değillerse, stokastik (tahminlenemeyen), ya da deterministik (tahminlenebilen) trend içermektedirler. Deterministik trend, oldukça uzun bir dönemde ortaya çıkan ve yükseliş ve alçalış zikzakları arasında belli bir yöndeki uzun dönemdeki eğilimi ifade etmektedir. Zaman serisi içerisinde trendin bütünü ile kestirilebilir oluşu deterministik trende işaret etmektedir ve $Y_{t}=\alpha+\beta t+\varepsilon$ eşitliğiyle gösterilebilir (Diebold ve Senhadji, 1996: 3-9). Eğer rastgele yürüyüş (random walk) modelini ifade edecek olursak $Y_{t}=Y_{t-1}+\varepsilon$ eşitliği ise, stokastik bir trendi ifade eder (Mankiv ve Sharppiro, 1985: 165-174). Yine stokastik ve deterministik trendin birlikte gösterimi de mümkündür (Charemza ve Deadman, 1997: 84-95). Durum, trend durağan süreç (trend stationary process) ve diferansiyel durağan süreç (difference stationary process) açısından incelediğinde, zaman serisine yapılacak doğrusal trend ilavesi ile yani trendsizleştirme sonucunda, eğer zaman serisi durağan hale geliyorsa, bu zaman serisinin deterministik bir trende sahip olduğunu; ancak eğer doğrusal bir trend ilavesi, zaman serisini durağan hale getirmiyorsa, bu durumda fark alınarak zaman serisi durağan hale getirileceğinden, stokastik bir trende sahip olduğu söylenebilir (Enders, 1995: 155-195).

Şekil 1'de BİST 100 endeksinin 1988-2015 zaman aralığındaki kapanış verileri bir zaman serisi olarak verilmiştir. Bu endeksin bu zaman aralığında bir trend içerdiği ve dolayısıyla durağan olmadığı söylenebilir. Durağanlığın test edilmesinde korelogram testi, birim kök testi gibi testler kullanılır. Farklı $\tau$ değerleri için $r_{\tau}$ otokorelasyon katsayılarının bir grafik üzerinde gösterimine korelogram denmektedir. $\rho_{\tau}$ fonksiyonu ana kütlenin korelogramını verir ve $\tau$ 'ye göre çizildiğinde korelogram grafiği elde edilir. Daha önce tanımlanan ana kütle $(\tau)$ dereceden otokorelasyon fonksiyonu, örnekten $r_{\tau}$ şeklinde tahmin edilebilir.

$$
\begin{gathered}
\rho_{\tau}=\frac{\lambda_{\tau}}{\lambda_{0}}=\frac{\text { gecikme } \tau \text { iken ortak varyans }}{\text { varyans }}-1<\rho_{\tau}<1 \\
r_{\tau}=\frac{\sum_{t=\tau+1}^{n}\left(X_{t}-\bar{X}\right)\left(X_{t-\tau}-\bar{X}\right) / n}{\sum_{t=1}^{n}\left(X_{t}-\bar{X}\right)^{2} / n}
\end{gathered}
$$

Görüldüğü gibi, örnek otokorelasyon fonksiyonu $\tau$ gecikme için, $\tau$ gecikmeli kovaryansın, varyansa oranı şeklinde tanımlanmakta ve Eşitlik 2'de $n$ serbestlik derecelerini sadeleştirerek basit bir şekilde tahmin edilebilmektedir. Tahmin edilen bu otokorelasyon katsayıları, gecikme değeri ile anlamlı bir şekilde hareket ediyorsa, yani aralarında anlamlı bir bağıntı varsa, bu durağanlığın bozulduğunun anlamlı bir göstergesidir. Birim Kök Testi ise, 
bir serinin uzun dönemde sahip olduğu özellik, değişkenin bir önceki dönemde aldığ1 değerinin, bu dönemi nasıl etkilediğinin belirlenmesiyle ortaya çıkartılabilir. Bu nedenle serinin nasıl bir süreçten geldiğini anlamak için, serinin her dönemde aldığ değerin daha önceki dönemlerdeki değerleriyle regresyonunun bulunması gerekmektedir. Zaman serilerinin durağanlığını test etmek için birim kök testlerin kullanılması, standart bir test haline gelmiştir. Bu amaçla geliştirilen birim kök testi ile serilerin durağan olup olmadıkları belirlenebilmektedir. Ele alınan zaman serisi için birinci dereceden otoregresif model için;

$$
A R(1)=X_{t}=\rho X_{t-1}+\varepsilon_{t}
$$

burada $\varepsilon_{t}$ stokastik hata terimi olup ortalamas1 sifir, varyans1 sabit, ortak varyans1 sifir olup otokorelasyonsuzdur $\left(E\left[\varepsilon_{t}\right]=0, \operatorname{var}\left(\varepsilon_{t}\right)<\infty\right.$, tüm $\mathrm{s} \neq 0$ için $\left.\operatorname{corr}\left(\varepsilon_{t}, \varepsilon_{t-s}\right)=0\right)$. Hata terimi $\varepsilon_{t}$, beyaz gürültü (white noise) hata terimi olarak bilinir. Sonuç olarak, $\rho \geq 1$ ise seri durağan değil, $\rho \leq 1$ ise seri durağandır.

Konuyu biraz daha detaylı olarak açıklamak gerekirse, zaman serilerinin frekans düzleminde analizi olan spektral analiz, esasında uygulamalar için farklı bir yaklaşım getirmiştir. Spektral analiz, zaman serilerinin güç spektrumunun tahmininde kullanılan bir istatistik yöntemidir. Güç spektrumu, otokovaryans fonksiyonunun Fourier dönüşümünü temsil eder, bir başka deyişle güç spektrumu, frekans domainindeki otokovaryans fonksiyonudur. $\mathrm{Bu}$ analiz, serilerin özellikleri hakkında genellikle faydalı bilgiler sağlamaktadır. Clive Granger 1960'l1 yıllarda hisse senedi, faizler, GSMH gibi sabit bir noktaya dönmeden, uzun dönemler boyunca hareket eden ekonomik değişkenleri analiz etmek için o günkü istatistik yönetmelerinin yetersiz olduğuna dikkat çektiğinde, Princeton Üniversitesi’nin Zaman Serileri Ekonomik Araştırma Programını tamamlamış ve Spektral Analiz modelini geliştirmiştir. Spektral analiz tekniği ile konjonktür (döngüsel, devresel) olgular incelenebilecek ve ekonomik değişkenlerin değişimi formunda olan zaman serilerine uygulanabilecektir. Spektral analiz tekniği, ekonomistlerin ekonomik veriler arasındaki geri bildirim sorunlarının çözmesine yardım etmiş, ayrıca ekonomik zaman serileri verilerinin ekonomistler tarafından daha gerçekçi ve doğru olarak hesaplanmasını sağlamıştır. Granger, spektral tekniğinin, konjonktür dalgalanmalara benzeyen, uygun olarak seçilmiş genlikli, fazlı ve birbirine yakın periyotlardaki sinüs serilerinin toplamı olarak değerlendirileceğinden, serilerin analizinde avantaj sağlayacağını belirtmiştir (Granger ve Hatanaka, 1964: 25-72).

Zaman serilerini analiz yöntemlerinden biri olan ve spektral analizin öncüsü olan periyodogram analizi tekniği, seride güçlü döngüsel bileşen olduğu zaman kullanılışlı bir yöntemdir (Nerlove vd., 1995: 22-23). Bununla beraber, toplam kareler (sum of squares - SS) tahmin yöntemiyle ilişkili olarak örnekleme hatalarına dayanan ciddi yanlışlıklar yapılabilmektedir. Bunun nedeni de, her bir frekansın periyodogram yoğunluğu etrafında oluşan güven aralığının oldukça geniş olmasıdır. Spektral analiz tekniği, bu örnekleme sorununu ortadan kaldırmak amacıyla geliştirilmiştir. Güç Spektrumu (Power Spectrum), periyodogramın hafifçe düzeltilmiş uyarlamasıdır. Periyodogramdan güç spektrumunu türetmek için, periyodogramın yoğunluğunun, birkaç komşu frekansın yoğunluk tahminlerinin dâhil olduğu ağırlıklı ortalama ile değiştirildiği düzgünleştirme (smoothing) yöntemleri kullanılır. Bu düzgünleştirme spektral pencere (spectral window) kullanılarak iki farklı şekilde yapılır. Birincisi, ağırlıklı ortalama içinde olan komşu frekansların bulunduğu pencerenin genişliği değiştirilebilir. İkincisi ise, ağırlıklı ortalamada hesabı farklı yapılabilir; bazı pencereler tüm frekanslara eşit ağırlık verirken, bazıları merkeze yakın olan frekanslara, 
kenardakilerden daha fazla ağırlık verir. Düzgünleştirme öncesi periyodogram oldukça köşeli ve sivri iken, düzgünleştirme sonrası oluşan güç spektrumu daha düzgündür. Periyodogramda, ayrık olan tepe noktaları birleşerek tek bir geniş tepe noktası haline gelebilirler ve düzgünleştirme örnekleme hatalarını azaltma eğiliminde olduğu için tahminler etrafındaki güven aralığı daralır. Periyodogram yönteminde, tüm zaman serisinin varyansını, ayrık frekans bileşenlerine bölümler ve her bir frekansla ilişkili olan kareler toplamını (sum of squares), yoğunluk olarak adlandırır. Spektrum yönteminde ise, bu kareler toplamı, komşu frekanslarla birlikte ortalaması alınarak varyans dağılımının tüm frekans bantları boyunca daha düzgün ve güvenilir tahmininin yapılması sağlanır. Burada, belirli bir frekans bandındaki varyansın tahmin değerini belirtmek için "güç" terimi kullanılır. Spektral tahmini, toplam güç miktarına (veya varyansa) bölerek de spektral yoğunluk (spectral density) bulunur ve spektral yöntemle ilgili bir standartlaşma sağlanır. Spektral yoğunluk, zaman serilerindeki belli bir frekans bandındaki varyans oranının tahmini sağlar ve değişik konular arasında karşılaştırmanın yapılmasını kolaylaştırır (Warner, 1988: 78-79).

Spektral analiz, özellikle incelenen zaman serilerine ait periyotların veya dalga boylarının uzun olması durumunda daha etkin sonuçlar vermektedir. Çok fazla sayıda periyodun veya dalganın olması durumunda zaman ekseni yerine frekans eksenini kullanmak daha rahat ve aydınlatıcı olabilir. Bununla beraber, az sayıda periyodun olması ve pek çok ekonomik veride olduğu gibi, bu periyotların boyunun ve genliğinin düzensiz olması durumunda frekans eksenini kullanmak fazla gerçekçi olmayabilir. Spektrumun düz olması (x-eksenine yatay), her bir bileşenin eşit ağırlığa sahip olduğunu, serinin korelasyonsuz veriler dizisinden oluştuğunu ve teknik olarak da bunun rastgele yürüyüş veya beyaz gürültü olarak yorumlanacağını gösterir. Eğer spektrum belli frekanslarda zirveler veya sivri noktalar gösteriyorsa da bu frekans veya frekansların serinin belirgin bir özelliğini gösterdiğini ve bu seride döngüsel hareketlerin olduğu söylenir.

Ayrıca, spektral analiz, trend ve periyodik olmayan yavaş faaliyetleri, düşük frekanslı bileşen; periyodik sürecin harmoniklerini ve periyodik olmayan hızlı faaliyetleri ise, yüksek hızlı bileşen olarak gösterebilir. Bu nedenle, ham veri üzerine yapılmış spektral analizlerdeki güç yoğunluklarının tepe noktaları, tam olarak periyodik sürece karşılık gelmeyebilir. Dolayısıyla, ham verinin öncelikle trendden arındırılması, elde edilecek sonucun verimliliği bakımından önemlidir. Bunun yanında, eğer zaman serisi durağan ise, veriden tek bir sonlu örnek alınarak yapılacak analiz, tutarlı tahminleri elde etmek için yeterli olacaktır. Bu önemli nokta, ergodik (ölçümkal, döngel) teorileri tarafindan matematiksel olarak da kanıtlanmıştır. Ergodiklik, gözlemlenen örnek momentlerin (ortalama, varyans, otokovaryans), tüm veriye yakınsadığını açıklamaktadır. Yukarıdaki sebeplerden dolayı, analiz sonucunda spektrumda belirlenen tepe noktalarının istatistiksel olarak anlamlı olması, temel varsayımların ihlal edilmediği anlamına gelir (Nerlove vd., 1995: 22-23).

Spektral analiz en basit şekilde, rastgele süreç teorisi (stokastik süreç) üzerine kuruludur ve kosinüs ve sinüs eğrilerinin toplanmasından elde edilen bir eğri formunu ifade etmektedir (Öğüt, 1988: 147-156). Sinüzoidal dalga aşağıdaki formülle gösterilebilir;

$$
f(t)=\alpha \cos (2 \pi f t-\beta) ; \quad p=\frac{1}{f}=\frac{2 \pi}{\lambda} ; \quad \beta=\xi \lambda
$$


Burada; $\alpha$ : Sinüzoidal dalganın genliğini, $f$ : frekansı (birim zamandaki döngü sayısını), $\beta$ : faz açısını, $\xi$ fazı göstermektedir. Frekans $(f)$, sinüzoidal dalganın birim zaman birimi içinde kaç kez tekrarlandığını gösterir. Birimi “devir/zaman” dır. Frekansın tersi (1/f) periyod (p) olarak adlandırılır. $\lambda=2 \pi f$ ise, sinüzoidalin açısal frekansıdır. Genlik $(\alpha)$, fonksiyonun sıfır düzeyinden doruk noktasına ölçüsüdür. Bir sinüzoidalin en büyük ve en küçük düzeyleri arasındaki fark $2 \alpha$ olur. Faz ( $\xi$ :), sıfır anına göre gecikmedir. Genliği ve frekansı belli bir sinüzoidalin evresi ile $t=0$ anına göre konumu da belirlenmiş olur. Sinüzoidalin $t=0$ anına göre en yakın doruğun uzaklığına faz kayması denir. Spektral analizin teorisinin iyi anlaşılabilmesi için, trigonometriyle ilgili kavram ve kuralların tekrar gözden geçirilmesinde fayda vardır.

Spektral analizini temelini oluşturan Fourier Analizi, Fourier teorisi, N/1, N/2, $N / 3, \ldots(N / 2) / 2$ veya 2 döngü uzunluğunda veya periyotta olan sinüzoidal bileşenlerin toplamının, $N$ uzunluğundaki zaman serisini yeniden oluşturabileceğini ifade etmektedir (Warner, 1988: 7). Değişik frekanslardaki sinüs ve kosinüs fonksiyonlarından oluşan bu fonksiyonlara Fourier Analizi ad1 verilir (Anders, 2011: 1-14). Fourier Analizi genel periyodik fonksiyonları, trigonometrik fonksiyonların bir toplamı olarak gösterme temeline dayanır. Bu analizin temel uygulamaları; 1şı̆̆ın, sesin ve diğer tüm radyasyon veya 1şınım dalgalarının araştırılmasıdır. İstatistik bilimi ise, zaman serilerinin Fourier gösterimiyle, tüm varyansa en büyük etkiyi yapan frekans bileşeniyle ilgilenmektedir. Bu bileşen tek bir frekanstan ziyade belli aralıkla oluşan frekans kümeleridir. $(\omega, \omega+d \omega)$ frekans bandı toplam varyansa $f(\omega) d \omega$ kadar katkıda bulunuyorsa; $f(\omega)$, serinin güç spektrumu fonksiyonu olarak adlandırılır. Ekonomistler açısından, güç spektrumunun uzun dönemli bileşenlerini bulunduran alçak-frekans aralığ trendin bulunması, sıfır frekansa çok yüksek bir değer verecektir, bu da yakındaki frekansların değerlerinin artmasına sebep olacaktır. Sızıntı (leakege) etkisi olarak da adlandırılan bu etkinin kaldırılması için, bu tür trendler belli yöntemlerle seriden çıkartılmalıdır. Ancak, spektral yöntemlerin etkin sonuç verebilmesi için sadece ortalamadaki değil, varyanstaki trendler de seriden uzaklaştırılmalıdır. Ancak, ekonomik serilerde bunu sağlamak yüzde yüz mümkün değildir. Serinin uzunluğu, uzun dönemli salınımları trendden ayırt etmeyi sağlayacak boyda olmalıdır. Ayrıca, doğru analizi yapabilmek için, uzun süreli serinin birden fazla tekrarının sağlanması ve belli zaman aralıkları ile elde edilmiş yeterli verinin toplanmış olmalıdır. Genelde, ekonomik zaman serileri 1şık, ses ve diğer radyasyon dalgaları olarak bilinen teknik dalgalara benzemeseler de; konjonktür dalgalanmalara, ekonomik hareketlere ve bu hareket içindeki otokorelasyon fonksiyonuna; ayrıca bu serilerin özelliklerinin veri dönüşümlerinin etkilerinin ölçülmesine, Fourier Analizi yöntemi ile farklı bir bakış açısı getirilebilir. Genel periyodik fonksiyonlar, sinüs ve kosinüs dalgalarının toplamı olarak kabul edilecektir ve trigonometrik polinomlar olarak adlandırılacaktır. Eğer, ele alınan periyodik fonksiyon sürekli ise, yaklaşık olarak şu fonksiyonla gösterebiliriz;

$$
f_{N}(t)=\frac{a_{0}}{2}+\sum_{k=1}^{N}\left[a_{k} \cos \left(\lambda_{\mathrm{k}} t\right)+b_{k} \sin \left(\lambda_{\mathrm{k}} t\right)\right]
$$

Formülde, “ $a_{k}$ ” ve “ $b_{k}$ ” sinüs ve kosinüs fonksiyonlarının " $k$ ” frekansındaki ağırlıklarıdır. Serilerin Fourier dönüşümü sırasında, sadece belli sayıda veya sayılabilir miktardaki veriler yerine, normal dağılıma sahip olan seriden mümkün olduğunca fazla veriyi 
değerlendirmek daha gerçekçi bir sonuç verecektir. Bu amaçla da, sonlu sayıdaki seriler yerine tüm hattı içeren entegral kullanılabilir (Granger ve Morgenstern, 1962: 3-7). Eşitlik 5'deki toplama, $-\pi \leq \omega \leq \pi$ aralığındaki sonsuz sayıda frekans dâhil edilerek, periyodik fonksiyonun mükemmel uyumu sağlanabilir. Burada, toplam işareti, entegral işareti ile yer değiştirirken, $a_{k}$ ve $b_{k}$ fonksiyonları ise integrali alınabilen ve sürekli $a(\lambda)$ ve $b(\lambda)$ fonksiyonları ile yer değiştirerek aşağıdaki eşitliğe dönüşür;

$$
f(t)=\int_{0}^{\pi}[\mathrm{a}(\lambda) \cos (t \lambda)+b(\lambda) \sin (t \lambda)] d \lambda=\int_{-\pi}^{\pi} \tilde{f}(\lambda) \mathrm{e}^{-\mathrm{i} \lambda t} d \lambda
$$

$f(t)$ fonksiyonu bilindiği zaman, Ters Fourier Dönüşümü $\tilde{f}(\lambda)$ yeniden yazılabilir.

$$
\begin{aligned}
\tilde{f}(\lambda) & =\frac{1}{2 \pi} \int_{-\pi}^{\pi} f(t) e^{i k t} d t \\
\phi & =\frac{b_{k}}{a_{k}} \text { ve } p_{k}=\sqrt{a_{k}^{2}+b_{k}^{2}}
\end{aligned}
$$

$\mathrm{Bu}$ eşitlikler yardımıyla, ele alınan serinin katsayılarını belirledikten sonra, Eşitlik 8’i kullanarak, $a_{1}, a_{2}, \ldots, a_{n}$ ve $b_{1}, b_{2}, \ldots, b_{n}$ katsayılarına karş1lık gelen, $p_{1}, p_{2}, \ldots, p_{n-1}$ değerleri bulunur; $a_{n}{ }^{2}$ de $p_{n}$ 'e karşıllk gelir. $p_{k}$ 'nın ana frekans $\lambda_{j}, \square 1, \ldots, n$ 'ye göre çizimine "spektrogram" denir. Gösterime bağlı olarak da, bazı durumlarda, $p_{k}, p_{k}{ }^{2}$ ile yer değiştirir veya ordinatlar periyod $\left(\frac{2 \pi}{\lambda_{j}}\right)$ boyunca gösterilir ve bu grafik de "periyodogram” olarak adlandırılır. Periyodogramın en kısa şekilde ifadesi;

$$
p_{j}^{2}=\frac{2}{T}\left|\sum_{t=1}^{T} y_{t} e^{-i \lambda_{j} t}\right|^{2}
$$

Fourier analizi ile spektral gösterim arasında çok da az olsa, bazı farklılıklar vardır. Bunlardan birincisi, stokastik sürecin bir parametresi olduğu için, spektral analizin gösteriminde matematiksel beklenti fonksiyonunun kullanılmasıdır. Çünkü, ekonomik uygulamalarda genellikle stokastik süreçten alınan bir örnek kullanılır. Bir başka anlatımla, ekonomik zaman serileri için spektral analiz tekniği, olasılık fonksiyonunu da içermelidir. İkincisi ise, Fourier analizi ayrık araklılarda kullanılırken, spektral analiz sürekli bir fonksiyon olarak kullanılır (Hatanaka, 1965: 6-15). Spektral analiz yöntemlerinin, zaman serilerini durağan olarak kabul etmesi ancak, ekonomik zaman serilerinin hiçbir zaman durağan olmaması nedeniyle başarılı olamayacağı düşünülür. Ancak, uygun spektral yöntemin seçilmesi ve doğru uygulanması ile gerçek analiz yapılabilir (Bátorová, 2012: 1215). 
Ekonomik verilerin spektral tahmini;

$$
f\left(\varpi_{j}\right)=\frac{1}{2 \pi}\left\{\lambda_{0} C_{0}+2 \sum_{k=1}^{m} \lambda_{k} C_{k} \cos \varpi_{j} k\right\} ; \quad \varpi_{j}=\frac{\pi j}{m}, \quad j=0, \ldots, m
$$

ve tahmin edilen kovaryanslar da aşağıdaki şekilde verilir;

$$
C_{k}=\frac{1}{n-k}\left\{\sum_{t=1}^{n-k} x_{t} x_{t+k}-\frac{1}{n-k} \sum_{t=1+k}^{n} x_{t} \sum_{t=1}^{n-k} x_{t}\right\}
$$

Burada; $\left(x_{t}, t=1,2, \ldots, n\right)$ verileri ve $\lambda_{k}$ da genellikle $m$ 'ye bağlı olan ağırlıkları göstermektedir. (Parzen, 1961: 167-190). Durağan serilerin bölünmesinden ortaya çıkan farklı salınımların genlikleri rastgele değerlerdir ve aldıkları değerler ile tanımlanırlar. Verilen her salınım periyoduna karşılık gelen varyans, incelenen sürecin spektrumunu belirler. Çeşitli sinüzoitler arasındaki farklar önemsizdir. Daha doğrusu, stokastik süreç $\left[X_{t}\right]^{\prime}$ nin spektrum fonksiyonu, sürecin ilişkilerinin Fourier ayrışmasındaki $\omega$ frekansın genliğinin karesinin beklenen değerinin çarpımsal sabitinin tanımladığı $f(\omega)$ fonksiyonudur. Spektrum, böylece, söz konusu olan süreçteki farklı frekansların önemini tanımlar. Hesaplamalar aşağıdaki şekilde yapılır. Durağan bir süreç için, yansız tahminci, sürecin tek bir defa gerçekleşmesinden hesaplanabilir. Sürecin $X_{t}$ ve $t=1,2,3, \ldots, T$ olduğu varsaydığımızda, tahminci periyodogramdır ve şu formülle gösterilir;

$$
I(\omega)=\frac{1}{2} \sum_{\theta=1}^{T-1} v_{\theta} \cos \omega \theta
$$

$v_{\theta}$, yaklaşı olarak ampirik otokovaryans ve $\bar{x}$ de serinin ampirik ortalaması olduğundan;

$$
v_{\theta}=\frac{1}{2} \sum_{\theta=1}^{T-\theta}\left(x_{t}-\bar{x}\right)\left(x_{t+\theta}-\bar{x}\right)
$$

Hiçbir yanlılık olmamasında rağmen, periyodogram, yakınsak olmadığında iyi bir spektrum tahmincisi değildir. $\mathrm{Bu}$ nedenle $I(\omega)$ fonksiyonu, $\omega$ ile değişen varyanslarının ortalama trendini temsil eden daha düzenli bir fonksiyonla gösterilebilir. Bu gösterime periyodogramın düzeltilmesi de denir ve şu şekilde gösterilebilir;

$$
f^{r(\omega)}=\frac{1}{2 \pi} \sum_{\theta=-m}^{m}\left(1+\cos \frac{\theta \pi}{m}\right) v_{\theta} \cos \omega \theta
$$

Bu formül Tuckey-Hanning'in tahmin fonksiyonu olarak adlandırılır. Diğer bir adı da "spektral pencere" (spectral window) dir. Diğer bir tahmin fonksiyonu da bitişik olmayan frekans bantlarında daha az sizıntıya neden olan Parzen'in tahmin fonksiyonudur, ancak bu fonksiyon ardışık tahmin değerleri arasında daha fazla korelasyona neden olur. Nihayet, spektrumun tahmini geliştirmek için, $X_{t}$ serisi öncelikle bir dönüşüme tabi tutularak, 
filtrelenmiş verilerin seriyi daha iyi temsil etmeleri sağlanabilir. Ayrıca, bilgisayar yazılımlarında temel alındığı için, $\lambda_{k}$ ’nın seçimi Tukey-Hanning tahmini için açıklanacaktır. Bunun dışında, Jenkins, Parzen, Hannan, Granander ve Rosenblatt gibi bilim insanlarının da, bu konuda çalışmaları olmuştur. Tukey-Hanning ağırlık eşitliği aşağıdaki şekilde verilebilir;

$$
\lambda_{k}=\frac{1}{2}\left[1+\cos \frac{\pi k}{m}\right]
$$

ve spektrumun tahmini için geçerli formül;

$$
\begin{gathered}
L_{j}=\frac{1}{2 \pi}\left(C_{0}+2 \sum_{k=1}^{m-1} C_{k} \cos \frac{\pi k j}{m}+C_{m} \cos \pi j\right) \\
U_{j}=0,25 L_{j-1}+0,50 L_{j}+L_{j+1}
\end{gathered}
$$

Burada; $L_{-1}=L_{+1}, L_{j-1}=L_{j+1}$ dir ve $L_{j}^{\prime}$ ler ham tahminleri, $U_{j}^{\prime}$ ler de düzleştirilmiş tahminleri verir ve özgün gösterimi $U_{j}=\hat{f}\left(\varpi_{j}\right)$ şeklindedir. Burada, Tukey-Hanning tahmininin $\left(\frac{\pi j}{m} \pm \frac{\pi}{2 m}\right)$ aralığındaki spektral kütle için verileceği bilinmelidir. Tukey-Hanning tahminin önemli avantajı, bir frekans bandından diğer frekans bandına çok küçük bir sızıntının olmasıdır. Tukey-Hanning tahminin dezavantajı, pozitif çıkması gereken tahminleri bazen negatif hesaplamasıdır. Literatürde ve ampirik uygulamalarda ise, genellikle Hodrick ve Prescott tarafından önerilen filtre yöntemi kullanılır (Hodrick ve Prescott, 1997: 1-16). Bu yöntem, uygulamadaki kolaylığı, pek çok istatistiki çalışmada yeterli sonuçlar vermesi, uluslararası ve ulusal pek çok çalışmadan otoriteler tarafından kullanılması nedeni ile öncelikle tercih edilmektedir (Diebolt ve Doliger, 2006: 39-47).

Daha önce de belirtildiği gibi, periyodik ve durağan olmayan bir serinin spektral dönüşümü, varyansın büyük bir bölümünü en düşük frekanslara dağıtacaktır. Tüm veriye doğrusal regresyon (linear regression) yöntemleri uygulanarak, seri trendden arındırılabilir. Bu yöntem, ancak ve ancak seri doğrusal veya düşük düzeyli (low order) trend içerdiğinde kullanılabilir. Ayrıca, düşük frekanslardaki sapmaların diğer nedenleri; ortalama değerin analizden önce seriden çıkarılmaması veya gerçek periyodik hareketlerin belirlenen en düşük frekans bandından daha yavaş hızda olmasıdır. Frekans bandının yanlış belirlenmesi durumunda, sapma yüksek frekanslardaki spektrumu da etkiyebilmektedir. Durağan olmama durumu için pek çok durum söz konusudur. Birinci durum, ortalamanın değiştiği, yani seride bir trendin olduğu durumlarda, spektrum sadece alçak frekanslarda yüksek değerlere sahip olacaktır. İkinci durum ise, varyansın sabit olmadığı hallerdir. Üçüncü durum ise, değişik frekanslardaki faz açısının zamanla değişmesidir; bu durum genellikle çapraz spektral analiz ile ilgilidir. Diğer bir durum ise, tüm parametrelerin zamanla değişebildiği dinamik ekonometrik modeldir. Durağan olmayan zaman serileri, bazı yöntemler uygulanarak (düzleştirme) durağan hale getirildikten sonra, spektral analiz yöntemi uygulanarak incelenebilir. Ancak, işlemden geçirilen verilerin, bazı özelliklerini kaybetme olasılığ mevcuttur. 


\section{KULLANILAN VERİ VE METODOLOJİ}

\subsection{Veri Seçimi}

Borsa İstanbul'dan elde ettiğimiz veriler, 4 Ocak 1998 - 8 Ocak 2015 tarihleri arasındaki Ulusal 100 Endeksinin, Türk Lirası hesaplamaları ile günlük kapanış değerleridir. BIST, 4 Ocak 1998 - 31 Aralık 1994 tarihleri arasında tek seanslı, 2 Ocak 1995 sonrasında ise çift seanslı olarak hizmet sunmuştur. Elimizde, 4 Ocak 1988 - 4 Ocak 2015 tarihi aralığındaki BİST Ulusal 100 verileri olmasına rağmen, 4 Ocak 1988 - 2 Ocak 1995 aralığındaki verilerin kullanılmaması değerlendirilecektir. Eldeki verilerin yapısının anlaşılması, analizin daha sonraki aşamalarının etkin olarak sonuçlandırılmasında çok önemlidir.

Mevcut verilerin, seans kapanış verileri olmasına rağmen; kullanacağımız programların, bilgi işlemci güçlerinin ve program bilgimizin, en fazla tarihsel verileri (haftalık) analiz yapabilmeye yeterli olması, tarih yanında saat verisiyle işlemlerde sağlıklı sonuç elde edememe olasılığ bulunması nedeniyle, analizlerde sadece haftalık kapanış fiyatları kullanılması uygun olacaktır. Bu konuda daha sonraki çalışmalarda, şartlar oluştuğunda, günlük ve her iki seans için ve hatta anlık değişimlere göre analizlerin yapılması denenebilir.

Kullanılacak veri, BİST Ulusal 100 endeksi haftalık kapanış verileri olduğuna göre, bu veriler bir tür örnek veriyi temsil etmektedirler. Borsa endeksi, her saniyede bir hesaplanan verilen olduğundan (www.borsaistanbul.com, 2016), sürekli veriler olarak sınıflandırılabilir. Spektral analiz yöntemiyle daha etkin bir sonuç çıkarmak için, tüm bu verileri incelemek gerekir. Günümüzün, teknolojisi bu bilgileri inceleme olanağına sahip olmasına rağmen, bu çalışmayı yaparken kullanılan bilgi işlem gücünün zayıflığı, depolama kapasitesinin azlığı, yazılım, bilgi ve deneyim eksikliği buna engel olmaktadır. Ancak, yine de BİST üzerine spektral analiz ile ilgili yapılan detaylı çalışma olması nedeniyle, sadece haftalık kapanış verilerinin spektral analiz ile incelenmesi bile mevcut olanakları oldukça zorlamaktadır.

\subsection{Metodoloji}

Veriler öncelikle hiçbir matematiksel işlem yapmadan, genel bilgi ve mantık çerçevesinde gözden geçirilmelidir. Verilerin ne yönde bir bilgi verdiği, içeriği, temel yapısı, ilişkileri iyice değerlendirilmelidir. Günümüzde teknoloji ne kadar gelişmiş olursa olsun, insanın sezgisel, mantıksal ve yüksek çözümsel analiz etme özelliklerini sağlaması olanaksızdır. Ancak, kullanılan sistemler, insanın bu özelliklerine yardımcı olabilir.

$\mathrm{Bu}$ genel düşünce çerçevesinde bu analizin yapılmasında aşağıdaki yöntemler izlenecektir:

i. Verilerin görsel olarak incelenmesi,

ii. Tanımlayıcı veya keşfedici istatistik (exploratory statistics) yöntemleriyle verilerin incelenmesi; tabloların, grafiklerin kullanılması,

iii. Verilerin ön işlemden geçirilerek, eksik, hatalı verilerin temizlenmesi, 
iv. Betimsel istatistik (descriptive statistics) yöntemleriyle verilerin temel istatistik incelemesinin yapılması; spektral modelin tanımlanması,

v. Çıkarımsal istatistik (inferential statistics) yöntemleriyle sonuçların çıkarılması, yorumlamaların ve tahminlerin yapılması.

Verilerin incelenmesi aşamasında, ham verilerle ilgili temel göstergeler kullanılmıştır. Daha sonra, haftalık veriler, tanımlayıcı istatistik yöntemiyle, öncelikle $\mathrm{R}$ istatistik programı kullanılarak, zaman düzleminde ve spektral düzlemde analiz edilmiştir. Haftalık veriler, Ulusal 100 endeksinin işlem gördüğü haftanın en son anındaki verileridir ve genellikle yedi gün arayla elde edilmiştir. Resmî ve dini tatillerle, diğer nedenlerden ötürü, yedi günün üstünde aralıklarla kayıt edilen veriler bulunmakta ancak, bu verilerin de daha düzenli zaman serileri olmaları sonucu, analiz edilmeleri ve içerdikleri döngülerin belirlenmesi daha kolaylaşmaktadır. Spektral analiz yönteminde, verilerin durağanlık şartı aranmaktadır. Spektral analiz yöntemlerinde, incelenen zaman serilerinin eşit aralıklarla elde edilmiş zaman serileri olması gerektiğinden, Ulusal 100 Endeksi haftalık kapanış rakamlarının kullanılması bu aşamada daha etkin bir yöntem olacaktır. Haftalık verilerin analizi, Ulusal 100 Endeksinin durağanlığı hakkında görsel kanının oluşmasını sağlayacaktır. Diğer klâsik istatistiki yöntemlerle de durağanlık ve serilerin diğer önemli özellikleri test edilecektir.

Analizin en son bölümünde ise, çıkarımsal istatistik yöntemleri kullanılarak, Ulusal 100 endeksinde tespit edilen döngüler yorumlanmıştır. Ayrıca, spektral analiz yöntemiyle analizin geliştirilebilmesi için yapılması gerekenler belirtilecek, özellikle disiplinler arası çalışmanın yapılması gerekliliği belirtilmiştir.

\subsection{R Programı Hakkında}

R programı, Bell Laboratuvarları (Lucent Technology - eski AT\&T firması) tarafından geliştirilen S yazılımının açı kodlu sürümü olup, istatistiki analizler için esnek ve güçlü bir ortam sağlamaktadır. R programı, hem doğrusal hem de doğrusal olmayan istatistiksel modellerin kurulup analiz edilmesinde çok geniş imkânlar sağlamaktadır. Ayrıca, yazılımın grafik özellikleri de son derece gelişmiştir (Venables vd., 2002: 1-15). Programın en önemli özelliği, açık kodlu bir yazılım olması, bu nedenle de bir lisanslama ücreti olmaması, dolayısıyla da bilim dünyasına hızlı ve yönlendirmesiz hizmet verebilmesidir. Program, bilim insanları tarafından, bilim insanlarının daha kolay bilim yapabilmeleri için yazılmıştır. Programın spektral analiz ile ilgili uygulamaları, önceki bölümde verilen teorileri temel alan ancak bugün daha da geliştirilmiş fonksiyonları kullanmaktadır.

R programı, özellikle ekonometri ve finansal analizler için çok sayıda uygulama modülüne (paket) sahiptir. Yazılımın, 64 bitlik çok çekirdekli paralel hesaplama özelliği ise, analizlerin çok hızlı yapılmasını sağlamaktadır. R programı için çok sayıda kaynağın ve çalışmanın bulunması, bu çalışmaların internet ortamında paylaşılması, diğer üstünlüklerindendir. R programı hakkında pek çok uluslararası bilim dergileri olumlu makaleler yazarken, pek çok internet tartışma ortamında (blog) programla ilgili deneyimler paylaşılmaktadır (McLeod vd., 661-712).

Çalışmada, R programının kullanılmasının temel amacı, yapılmak istenen her analizin kodlarla yazılarak yapılması; dolayısıyla özellikle spektral analiz gibi yeni çalışmaların da, daha sağlıklı yapılabilmesini sağlamaktır. R programı açık kod bir program olduğu ve çekirdek kodları istatistikçiler tarafından geliştirildiği için, diğer istatistik programlarında olmayan pek çok spektral analiz yöntemi, istatistik yazılımcıları tarafından geliştirilmiş ve R 
programına eklenmiştir. Bu çalışmada, $\mathrm{R}$ programının olanakları kullanılarak, hem zaman serileri, hem de klâsik spektral analiz paketleri de kullanılarak BİST Ulusal 100 Endeksi'nin frekans düzlemindeki modeli çıkarılacaktır.

R programı açık kodlu bir yazılım olduğu için, geliştiriciler tarafından değişik zaman aralıklarında güncellenmektedir. Çalışma R programının RStudio editör uygulamasının 1.0.153 sürümü kullanılmıştır. Kullanılan paketleri ise, zaman serilerinin analizi için "timeSeries" paketi, durağanlık analizi için "acf” ve "fUnitRoots" paketleri, bileşenlere ayırmak için "stats” paketi, klasik spektral analiz için ise "TSA" paketidir. R programının bu paketleri ve paketler içindeki fonksiyonlar kullanılarak, hem zaman serileri, hem de klasik spektral analiz hesaplamaları yapılacak ve BİST Ulusal 100 Endeksi'nin frekans düzlemindeki modeli çıkarılacaktır.

\section{SPEKTRAL ANALIZ YÖNTEMININ BIST 100'E UYGULANMASI}

BİST Ulusal 100 Endeksi için elimizdeki veri, başlangıcından itibaren olmakla birlikte, yirmi yedi yıllık bir veridir. Ayrıca, Tablo 1'de görüldüğü gibi, 1995 yılına kadar olan verileri kullanmak, analizimize fayda değil, yanlılık (bias) getirme olasılığı yüksektir. Çünkü:

i. 1986 yılında faaliyete geçen borsanın ilk yıllardaki verileri, analiz için yanıltıcı olabilir.

ii. $\quad 1988$ - 1995 yılları aralığında borsada işlem gören şirket sayısı, işılem miktarı, işlem hacmi ve BİST 100 endeksi bilgileri çok küçük değerlerdedir.

iii. Borsada, 1995 yılında çift seans uygulamasına geçilmiş ve bugüne kadar çift seans uygulaması devam etmiştir. Dolayısıyla, 1995'den itibaren elde edilen veriler, eşit işlem süresinde yapılan işlemler sonucu elde edilmiş verilerdir.

iv. Şekil 1, 4 Ocak 1988 - 4 Ocak 2015 tarihleri arasındaki Ulusal 100 Endeksi grafiğini göstermektedir. Grafik, 1995 yılından itibaren sürekli artan bir trende sahip olmuştur.

Bu şartlar altında, 1995 yılında dahi borsa verileri, gelişmekte olan ülkeler borsalarının özelliklerine ulaşmamış olmasına rağmen, spektral analizin belli bir tarihsel uzunlukta veriye gereksinim duyması nedeniyle, Ulusal 100 endeks verilerinin spektral analizi için, başlangıç noktası 2 Ocak 1995 olarak alınmıştır. Şekil 1'de görüldüğü üzere, Ulusal 100 endeksinin, bir trende ve konjonktür dalgalanmalara sahip olduğu kesindir. 
Tablo 1. BİST Tarihsel Veriler Tablosu

\begin{tabular}{|c|c|c|c|c|c|}
\hline Yillar & $\begin{array}{l}\text { İşlem Gören } \\
\text { Şirket Sayısı }\end{array}$ & $\begin{array}{c}\text { Toplam İșlem } \\
\text { Miktarı (Milyon } \\
\text { USD) }\end{array}$ & $\begin{array}{l}\text { Toplam İşlem } \\
\text { Hacmi (000) }\end{array}$ & $\begin{array}{c}\text { (BİST100) } \\
\text { Endeksi (TL) }\end{array}$ & $\begin{array}{c}\text { (BİST100) } \\
\text { Endeksi (USD) }\end{array}$ \\
\hline 1986 & 80 & 13 & 3,273 & & \\
\hline 1987 & 82 & 118 & 14,731 & 6,89 & 393,47 \\
\hline 1988 & 79 & 115 & 31.679 & 3,74 & 119,82 \\
\hline 1989 & 76 & 775 & 238,056 & 22,18 & 560,57 \\
\hline 1990 & 110 & 5.851 & $1.537,387$ & 32,56 & 642,63 \\
\hline 1991 & 134 & 8.536 & $4.531,153$ & 43,69 & 501,49 \\
\hline 1992 & 145 & 8.567 & $10.285,263$ & 40,04 & 272,61 \\
\hline 1993 & 160 & 21.771 & $35.249,007$ & 206,83 & 833,28 \\
\hline 1994 & 176 & 23.202 & $100.062,030$ & 272,57 & 413,27 \\
\hline 1995 & 205 & 52.357 & $306.253,734$ & 400,25 & 382,62 \\
\hline 1996 & 228 & 37.737 & $390.917,238$ & 975,89 & 534,01 \\
\hline 1997 & 258 & 58.104 & 919.783,736 & $3.451,26$ & 982,07 \\
\hline 1998 & 277 & 70.396 & $2.242 .531,233$ & $2.597,91$ & 484,01 \\
\hline 1999 & 285 & 84.034 & $5.823 .858,228$ & $15.208,78$ & $1.654,17$ \\
\hline 2000 & 315 & 181.934 & $11.075 .884,720$ & $9.437,21$ & 817,49 \\
\hline 2001 & 310 & 80.400 & $23.938 .148,750$ & $13.782,76$ & 557,53 \\
\hline 2002 & 288 & 70.756 & $33.933 .250,900$ & $10.369,92$ & 368,26 \\
\hline 2003 & 285 & 100.165 & $59.099 .780,410$ & $18.625,02$ & 778,43 \\
\hline 2004 & 297 & 147.755 & $69.614 .651,500$ & $24.971,68$ & $1.075,12$ \\
\hline 2005 & 306 & 201.763 & $81.099 .503,190$ & $39.777,70$ & $1.726,23$ \\
\hline 2006 & 322 & 229.642 & $91.634 .552,160$ & $39.117,46$ & $1.620,59$ \\
\hline 2007 & 327 & 300.842 & $116.824 .184,900$ & $55.538,13$ & $2.789,66$ \\
\hline 2008 & 326 & 261.082 & $114.796 .860,900$ & $26.864,07$ & $1.027,98$ \\
\hline 2009 & 325 & 316.326 & 205.986.913,300 & $52.825,02$ & $2.068,18$ \\
\hline 2010 & 350 & 425.747 & $204.083 .247,400$ & $66.004,48$ & $2.499,75$ \\
\hline 2011 & 375 & 423.851 & $202.149 .186,200$ & $51.266,62$ & $1.580,45$ \\
\hline 2012 & 422 & 348.606 & $174.290 .128,500$ & $78.208,44$ & $2.561,94$ \\
\hline 2013 & 438 & 431.273 & $198.857 .864,700$ & $67.801,73$ & $1.853,28$ \\
\hline 2014 & 437 & 399.145 & $207.100 .459,60$ & $85.721,13$ & $2.145,18$ \\
\hline
\end{tabular}

Kaynak: BİST

Spektral analiz testlerinin doğru yapılabilmesi, ele alınacak zaman serisinin içindeki döngülerin doğru tespit edilmesiyle başlar. Dolayısıyla, yapılacak örneklemelerin ve zaman serisinin boyutunun doğru tespiti en önemli gerekliliktir. Çalışmamızda, bizi en fazla zorlayacak konu, BİST'in yeni bir borsa olması ve bu nedenle, BİST Ulusal 100 Endeksinin yeterli uzunlukta veriye sahip olmamasıdır. BİST'in maksimum veri uzunluğu 30 yıldır; dolayısıyla da, analiz edilebilecek en uzun döngü de 30 yıldır. Ancak, sağlıklı analiz yapılabilmesi, veri uzunluğunun en uzun döngüden yedi kat daha uzun olması gerekmektedir. Dolayısıyla, bizim sağlıklı olarak belirleyebileceğimiz en uzun döngü süresi 4,3 yıl yani, dört yıl ve dört aydır.

BİST Ulusal 100 Endeks verilerinin günlük ve seanslık kapanışları kayıt altında olduğundan ve resmî kaynaklardan bu bilgilere erişilebildiği için; tüm analiz, kapanış anındaki durumu gösteren ve burada belirtilen seans kapanış değerlerine göre yapılabilecektir. 
Ancak, endeksin gün içindeki değerlerinin kayıtlı ve elde edilebilir olmaması, gün içinde oluşan döngüleri analiz edebilmemizi engellemektedir.

Gün içindeki değişimlerin analiz edilememesi ise, spektral analizin, 10 dakika, 30 dakika, 60 dakika, 2 saat, 3 saat aralıklarındaki kısa süreli döngüleri belirleyememesini, dolayısıyla da saatlik olayların endeks üzerindeki etkisinin analiz edilmesini engelleyecektir. Ancak, daha evvel de belirttiğimiz gibi, bu verilerin elde edilmesi durumunda bile, teknik olanakların yeterli olmaması nedeniyle de gün içindeki değişimlerin analizlerinin yapılabilmesi oldukça zordur. Bu analizde kullanılacak veriler, haftalık borsa seans kapanış endeksi olduğundan, veriler haftanın en son işlem gününün öğleden sonra seansının kapanışı olarak alınacaktır.

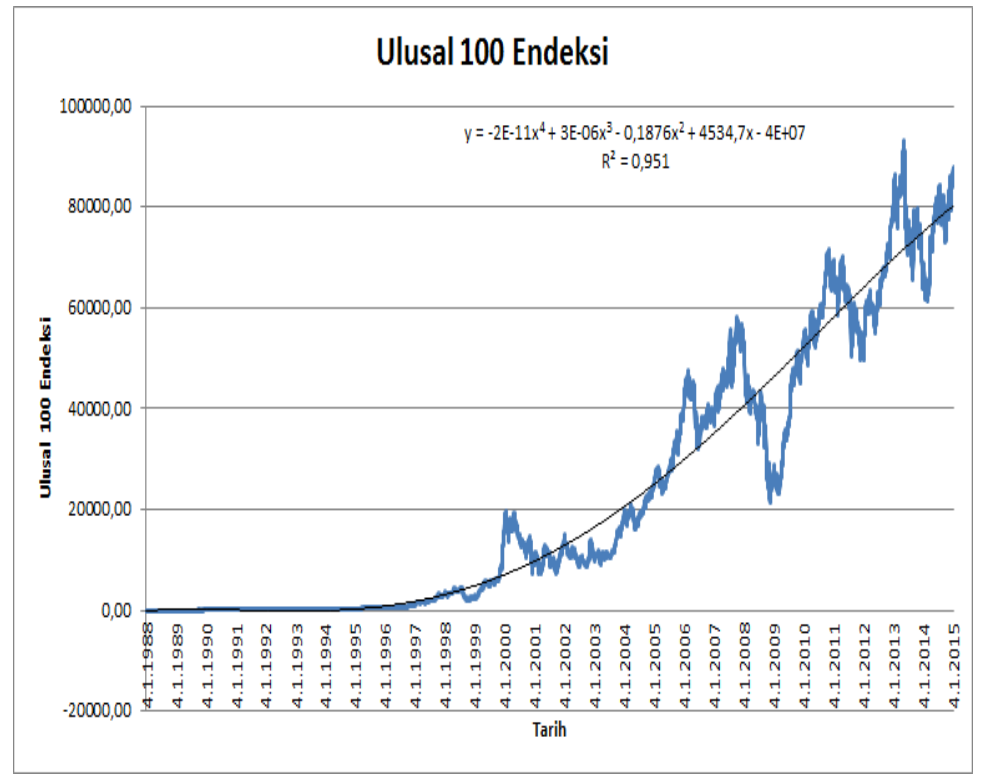

Şekil 1. 1988 - 2015 Ulusal 100 Endeks Grafiği - TL Cinsinden
Seans kapanışlarıysa, istisnalar hariç genellikle aynı saatte olduğu için verilerimiz olay temelli olmasına rağmen, zaman haftalık ekseninde gösterilerek, analizin yapilması kolaylaştırılacaktır. Veriler BİST'in elektronik sisteminden kaydedilmiş ve borsanın resmi veri bankasından temin edilmiştir. Haftalık kapanış verileri, spektral analiz için en uygun veri olan sürekli gerçek aralıklı oranlı ölçülmüş veriler olarak değerlendirilebilir. Hafta sonu, resmi ve dini tatiller ve bazı özel durumlar nedeniyle oluşan kaymalar dikkate alınmamıştır.

\subsection{Verilerin Durağanlığının İncelenmesi}

Ortalamanın ve varyansın zamanla değişmemesi, otokorelasyonun da zamanla değil, gecikme ile değișmesinin durağanlık şartı olduğu göz önüne alındığında, öncelikle yukarıdaki bölümdeki görsel analizlerde, verilerin durağan olmadığı belirlenmiştir.

İstatistik testlerini kullanarak durağanlık analizini ise, $\mathrm{R}$ programında acf fonksiyonu ile korelogramını inceleyerek, fUnitRoots paketini kullanarak da birim kök testiyle yapılabilir. 


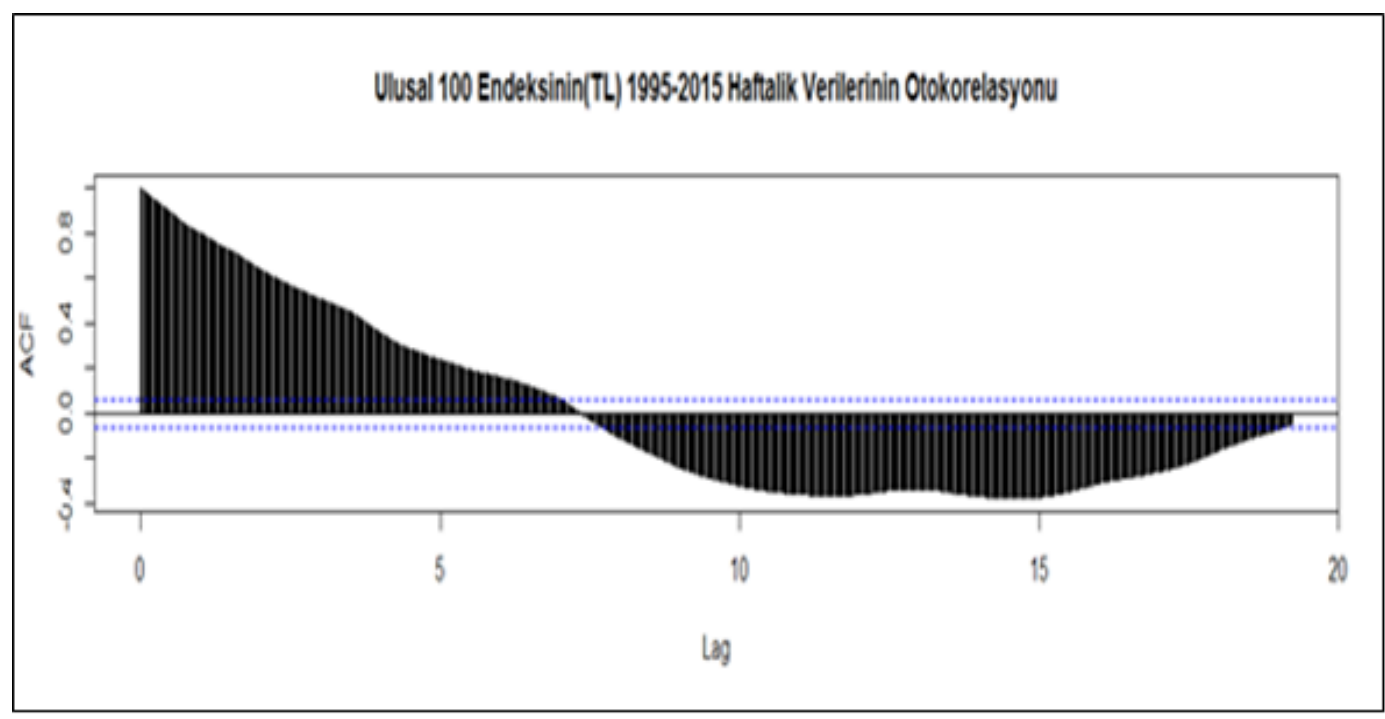

Şekil 2. TL Bazlı Ulusal 100 Endekslerinin 1995-2015Aralığında Haftalık Kapanış Verilerinin Korelogram 1

Durağanlık araştırmasındaki ikinci adım, TL Bazlı Ulusal 100 endeksinin korelogramını incelemektir. Bir zaman serisi durağan ise, otokorelasyon fonksiyonunun birinci veya ikinci gecikmede sıfırı kesmesi gerekir. Bir seride gecikme sayısı artırıldığında otokorelasyon fonksiyonunun aldığı değerler sıfira yaklaşıyorsa seri durağandır, aksi halde durağan değildir. Şekil 2'de hem Ulusal 100 Endeksinin haftalık kapanış değerlerinin korelogramı R programı yardımıyla çizilmiştir. Burada, her iki grafikte de Ulusal 100 Endeksinin otokorelayonu, birinci ve ikinci gecikmelerde sıfırı kesmemekte, yavaş azalan bir eğimle sıfıra yaklaşmaktadır; dolayısıyla serilerin, otokorelayon incelemesi sonucu durağan olmadıkları söylenecektir.

Durağanlık araştırmasında üçüncü adım; birim kök testleridir. Daha önceki bölümlerde de belirttiğimiz gibi; birim kök bulunan bir seri, rastgele yürüyüş özelliği gösteren bir seri olarak ifade edilir ve zayıf formda etkinliğinin kabul edilmesini gerektirir. Durağan bir seride ani şoklar sonucu ortalama (veya trend) değerinden sapmalar olsa dahi, değerler zamanla ortalama (veya trend) değerine yaklaşır. Bu trendden geçici sapmalar olsa bile, zaman içinde serilerin trend değerine döneceği, şokların bertaraf edileceği anlamına gelir. Ancak, değişkenler üzerindeki etkileri birkaç dönemde yok olan geçici şokların yanında, etkileri uzun süre devam eden kalıcı şokların varlığı da bilinmektedir. Birim kökün varlığı, bu kalıcı şoklara işaret eder. Çünkü, kalıcı şokların oluşturduğu trend, serinin belirli bir değere doğru yaklaşmasını engellemektedir. Değişkenlerin belirli bir değere yaklaşması olarak tanımlanan durağanlık açısından, bu trend, durağan olmayan bir özellik taşır ve şokların tanımı gereği, önceden öngörülemeyen tesadüfi niteliğinden dolayı, stokastik trend olarak adlandırılır. Birim kök testiyle de, bu trendin varlığı test edilebilir.

Hem Ulusal 100 endeksine uygulanan, Dickey-Fuller, Augmented Dickey-Fuller istatistik birim kök testlerinin sonuçları aşağıdadır: 
Testlerde $\mathrm{p}$ değeri $\% 5$ istatistiksel anlamlılık değerinden büyüktür, dolayısıyla serilerin durağan olmadıkları istatistiksel testlerle de kanıtlanmıştır.

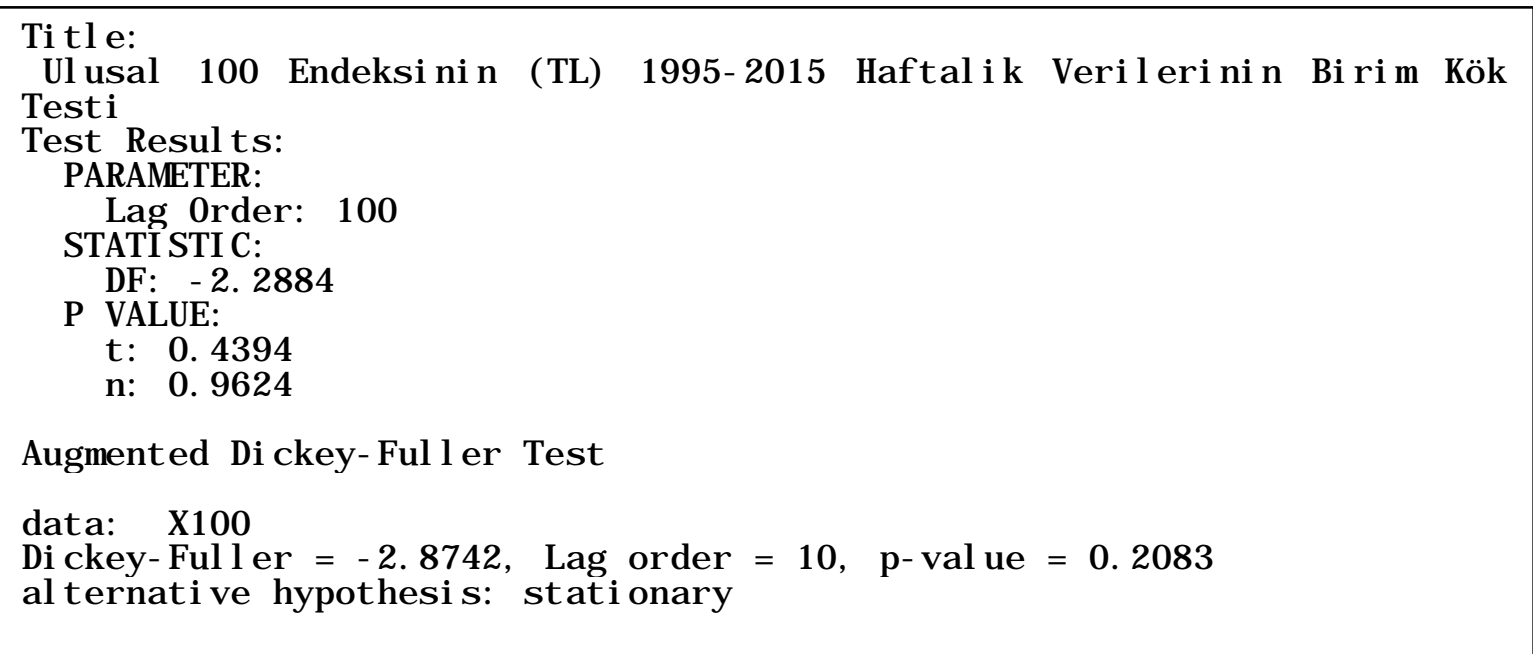

Bir sonraki aşamada ise, $\mathrm{R}$ programını kullanarak, durağan olmayan ham zaman serileri bileşenlerine ayrıştırılabilir. Böylece, spektral analiz yöntemiyle analiz etmeden önce, serilerin hangi periyotlarda döngülere sahip olabilecekleri konusunda bir ön fikir edinilebilir. R programının "stats" paketinden decompose() fonksiyonu kullanılarak elde edilen ve 19952015 yılları aralığında TL bazlı Ulusal 100 Endeksinin haftalık kapanış verilerini (sol üst), trend (sağ üst), mevsimsel (sol alt) ve rastgele (sağ alt) bileşenleri Şekil 3 ’te gösterilmektedir.

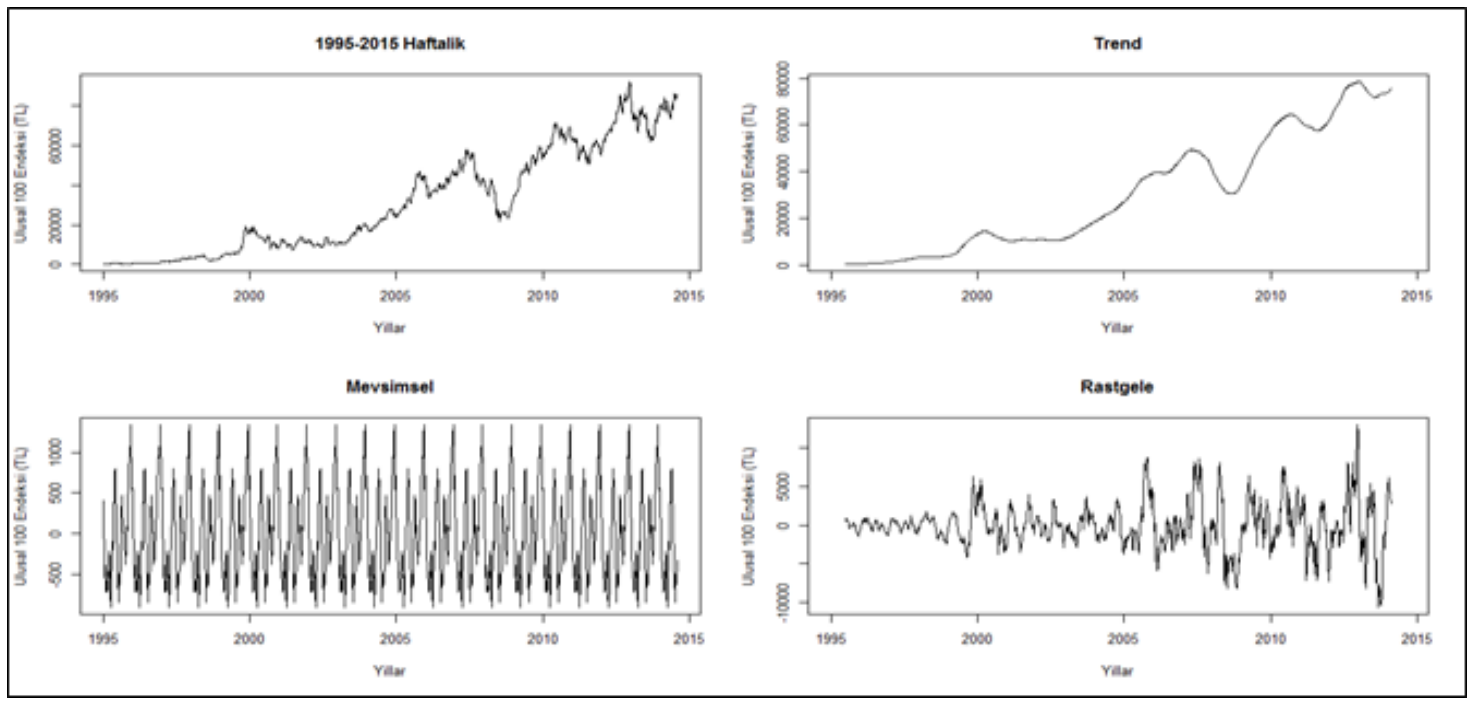

Şekil 3. Ulusal 100 Endeksinin 1995-2005 Aralığındaki Haftalık Kapanış Değerleri ve Trend, Mevsimsel ve Rastgele Bileşenleri 
Yapılan analizler sonucunda, Ulusal 100 Endeksinin haftalık kapanış verilerinin durağan bir yapıda olmadıklarını, trende, mevsimsel ve rastgele bileşene sahip olduklarını göstermektedir. Özellikle, grafiklerde trend bileşeninin aşağı ve yukarı hareketlilik göstermesi, Ulusal 100 Endeksinin ayrıca konjonktür dalgalanma içerebileceğini göstermektedir. Verilerin daha iyi incelenebilmesi için, bundan sonraki bölümlerde daha etkin yöntemler kullanılacaktır.

\subsection{Verilerin Klasik Spektral Analiz Tekniği ile İncelenmesi}

Öncelikle, 1995-2015 yılları arasındaki haftalık verileri incelenirse, Şekil 3'te gördüğümüz gibi, verilerin bir trende sahip olduğu ancak, trendin de dalgalı olduğu görülmektedir. Bu dalgalanma, verinin bir konjonktüre sahip olabileceğini göstermektedir. $\mathrm{Bu}$ nedenle öncelikle veriden trend bileşenini (X100T) ayırmak gereklidir.

$$
X 100_{\text {Trendsiz }}=X 100-X 100 T
$$

$X 100_{\text {Trendsiz_ }}$ verisi, Şekil 4'te gösterilmiştir. Ancak, trendi ayrıştırılmış verinin de görsel incelemesi ve birim-kök testleri yapıldığında, durağanlığın henüz sağlanamadığı ve bu nedenle spektral analizinin yapılmasının sağlıklı sonuç vermeyeceği söylenebilir. Bu nedenle, serinin birinci farkları alınarak düzleştirilmiş ve bu fark serisi durağanlık şartını sağlamıştır. Elde edilen düzleştirilmiş seri, Şekil 5'te gösteriliştir. Bu durumda, elde edilen seriye spektral analiz yöntemi uygulanabilir.

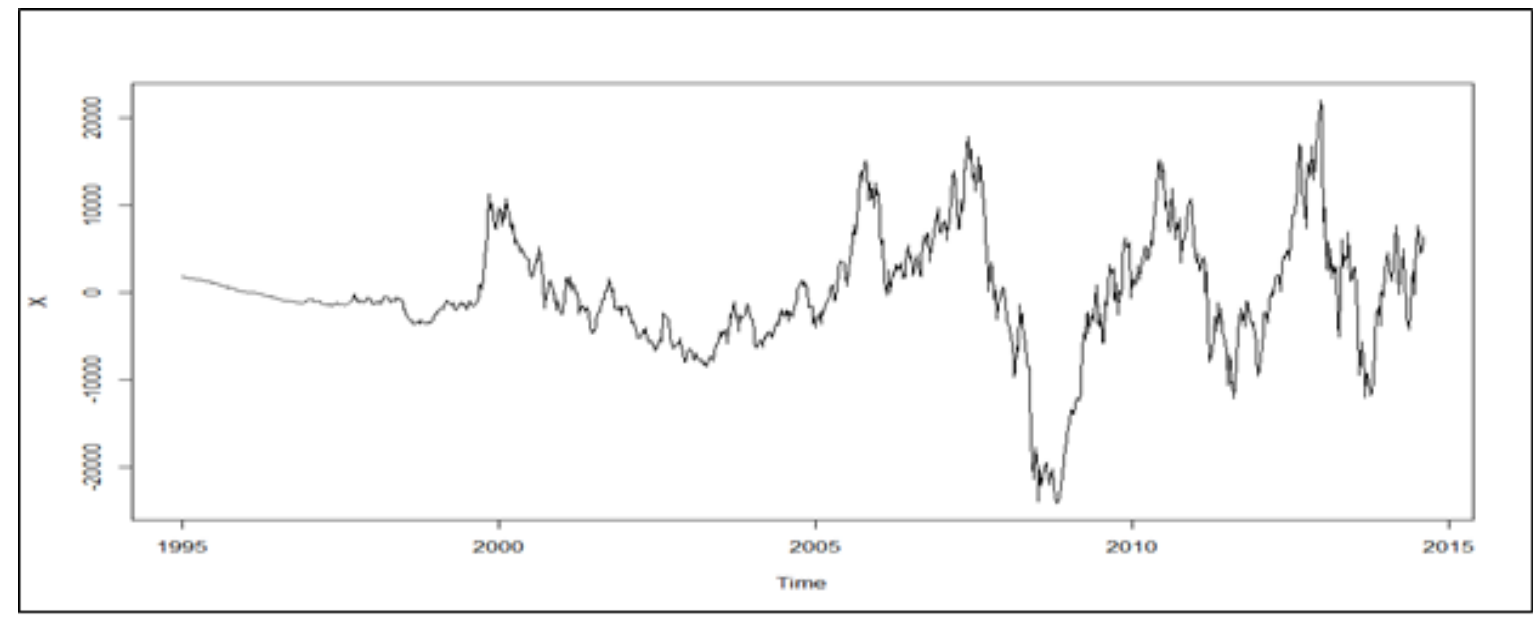

Şekil 4. Ulusal 100 Endeksinin 1995-2005 Aralığındaki Trendi Ayrıştırılmış Haftalık Kapanış Değerleri

Verilerin spektral analizi için, TSA eklentisinden spec() fonksiyonu ve/veya stats paketinden spectrum() fonksiyonu kullanılacaktır. Şekil 6'daki grafik, Granger'in New York borsası için yapmış olduğu çalışmayla benzerlik göstermektedir. Ancak, bu veriler ham olduğu için trend bileşenin varlığı sıfır frekansa yakın bölümdeki spektral yoğunluğu artırmaktadır. Diğer frekanslar; 25 hafta, 10 hafta, 8 hafta, 7,5 hafta, 5,5 hafta vb. gibi şeklindedir.

Ancak, bu analiz trend içerdiği için, çok doğru bir sonuç vermeyecektir. Daha uzun periyoda sahip döngüler, trend bileşeni nedeniyle kaybolmuştur. Şekil 7'deki grafik farkları alınarak 
düzleştirilmiş verinin, spektral yoğunluğunu göstermektedir. Verilerin 2 yıl konjonktür, 1 yıl, 4,5 ay gibi mevsimsel ve 2 ay, 1,5 ay, 1,2 ay, 1 ay, 20 gün ve 15 günlük periyotlarda rastgele dalgalanmalara sahip olduğu belirlemiştir. Bu dalgalanmalar içerisinde, 2 aylık, 1,2 aylık, 20 günlük ve 15 günlük dalgalanmaların tepe noktalarına sahip olması, BİST Ulusal 100 endeksinin belirtilen bu periyotlarda önemli dalgalanmalara sahip olduğunu göstermektedir.

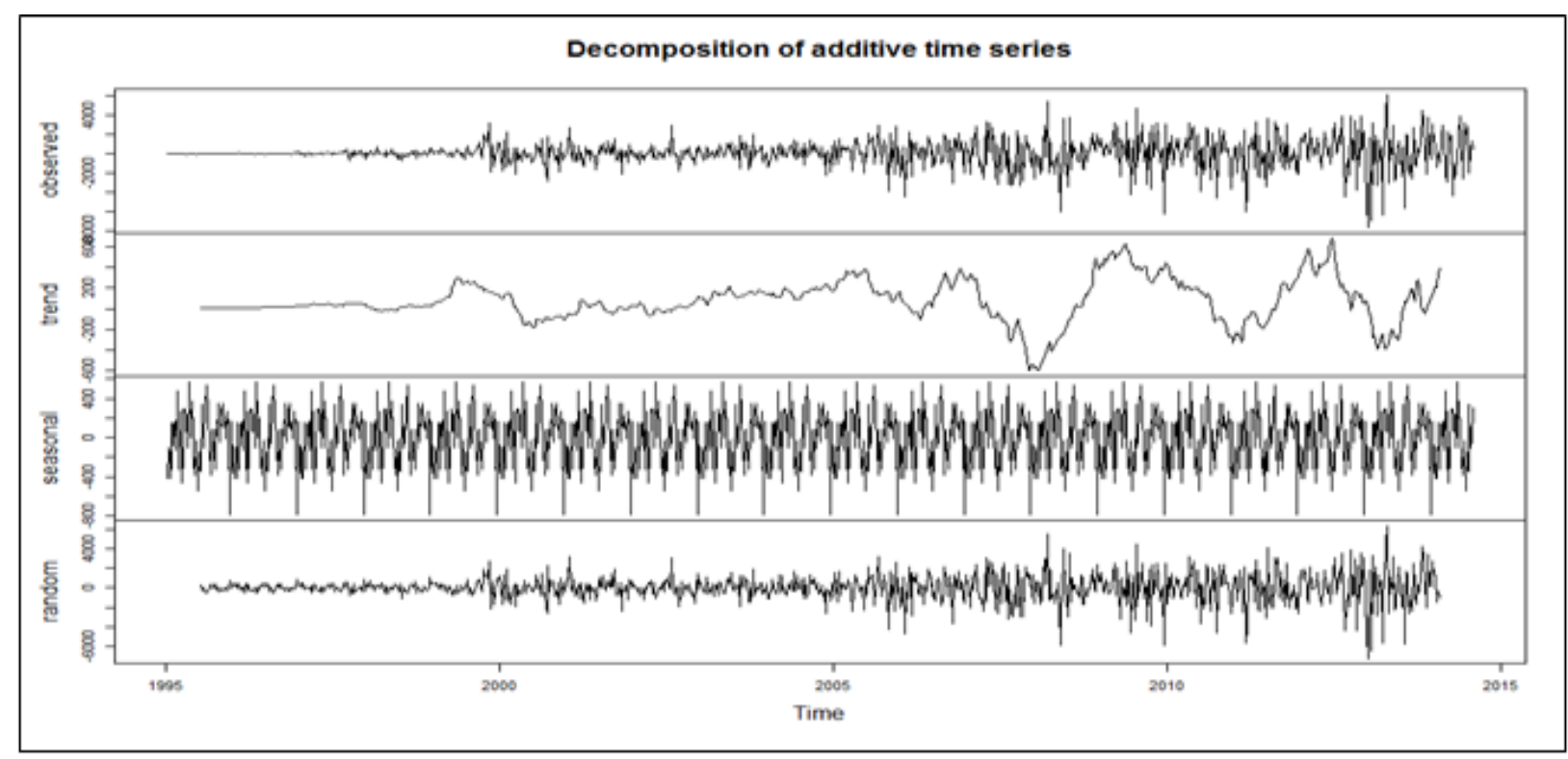

Şekil 5. Ulusal 100 Endeksinin 1995-2005 Aralığındaki Trendi Ayrıştırılmış Haftalık Verinin, Konjonktür (Trend), Mevsimsel ve Rastgele Değerleri Bileşenleri

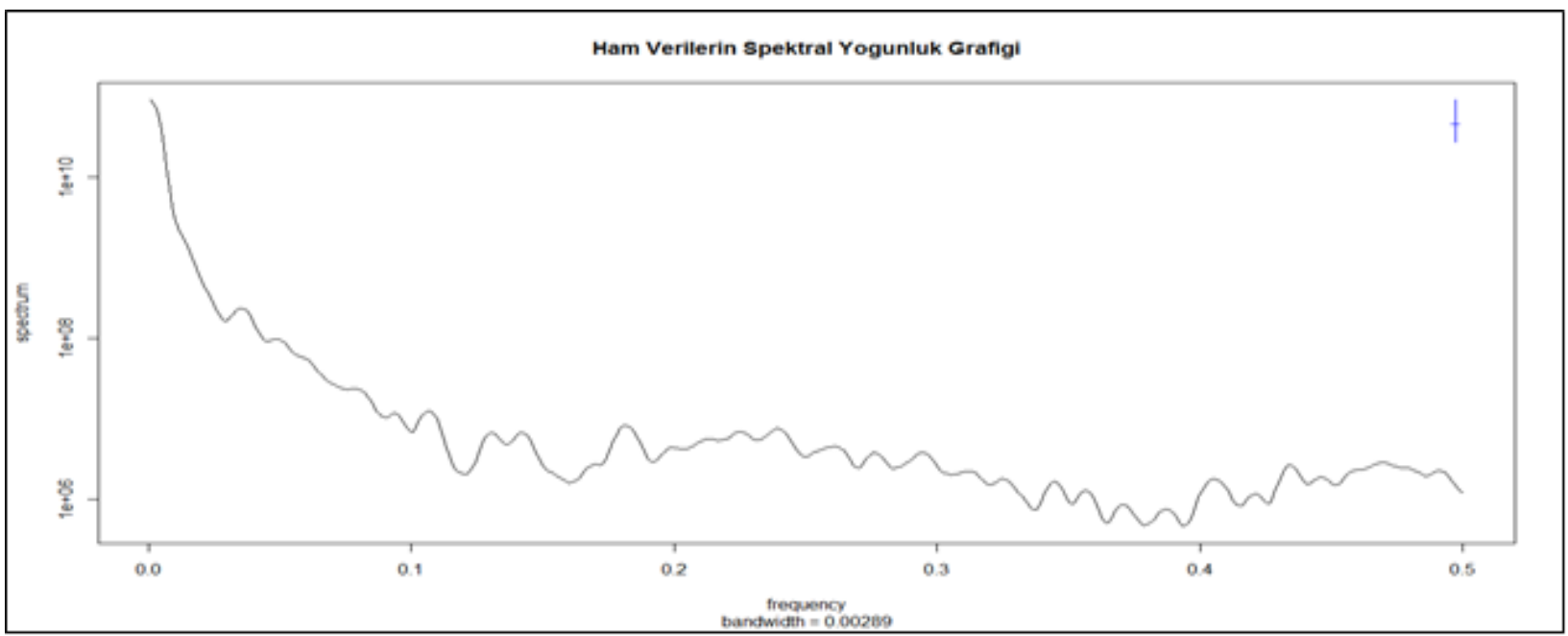

Şekil 6. Ulusal 100 Endeksinin 1995-2005 Aralığındaki Haftalık Ham Verinin Spektral Yoğunluk Grafiği 
Şekil 7. Ulusal 100 Endeksinin 1995-2005 Aralı̆̆ındaki Haftalık Düzleştirilmiş Verinin Spektral Yoğunluk Grafiğii.

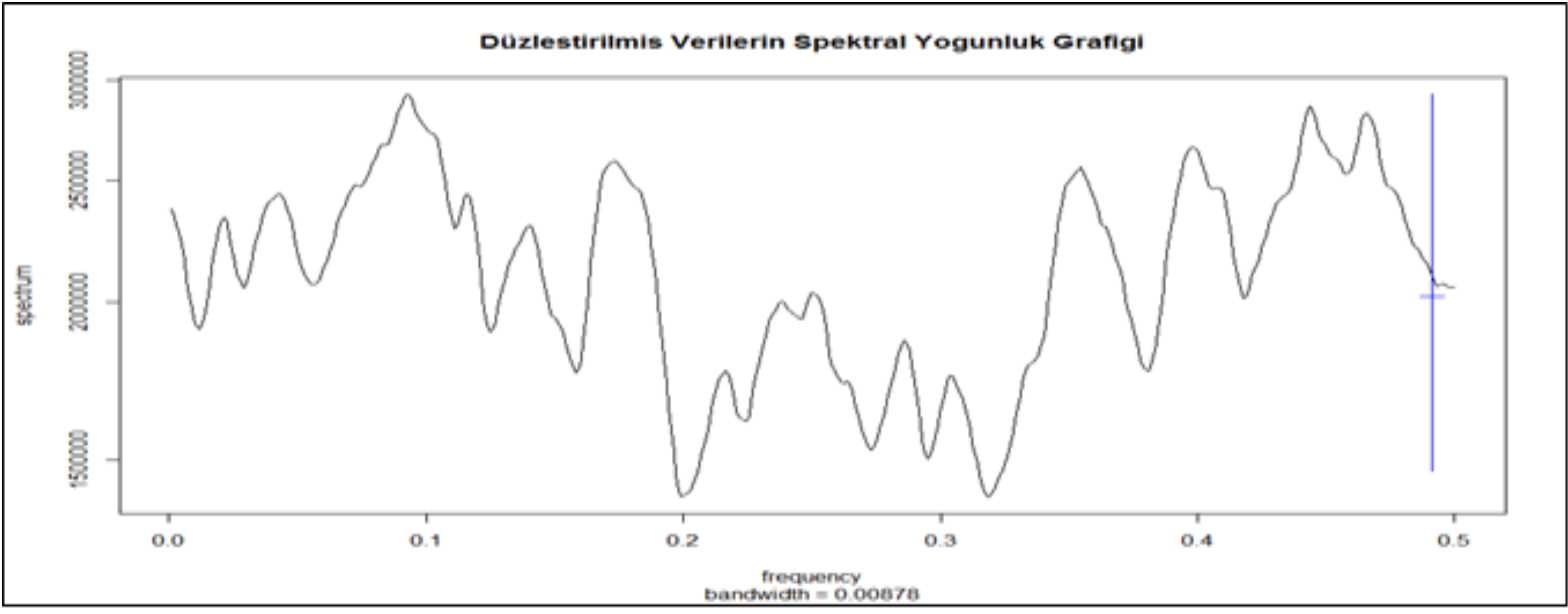

Şekil 7. Ulusal 100 Endeksinin 1995-2005 Aralığındaki Haftalık Düzleştirilmiş Verinin Spektral Yoğunluk Grafiği

\section{SONUÇ VE ÖNERILER}

BİST Ulusal 100 endeksinin, spektral analiz yöntemiyle incelenmesi, özellikle son 20 yıllık verilerin salınım özelliği göstermeleri nedeniyle beklenenden daha iyi sonuçlanmıştır. Çalışma 1986 yılında kurulan borsanın, 1995 yılından itibaren 2015 yılına kadar olan aralığındaki verileri, borsadaki salınımlarla ilgili bilgiler vermiștir.

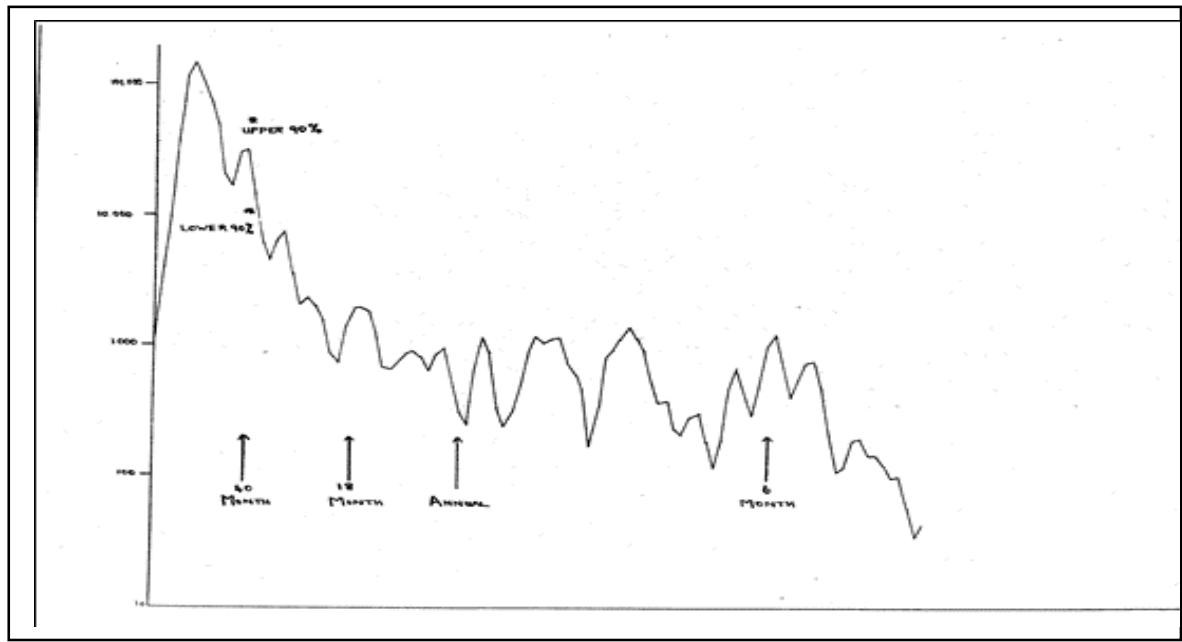

Şekil -8 Granger ve Morgenstern Tarafindan İncelenen S\&P Verileri

Graner ve Morgenstern, New York Hisse Senetleri piyasasını spektral analiz ile inceledikleri çalışmada gösterdikleri ekonomik serilere ait temel spektral şekil, BİST Ulusal 100 Endeksi'nin, Şekil 6'da verilen, ham verilerin spektral analizi grafiğiyle benzer 
karakteristiklere sahiptir. Burada, frekans sıfıra yaklaştıkça, spektrum sonsuza yaklaşmaktadır. Bu da serilerdeki trendin oluşturduğu bir durumdur.

Granger ve Morgenstern bu çalışmada ayrıca, Standard \& Poor Endeksi'nin Ekim 1875 - Mart 1958 tarihleri arlığındaki ve Dow-Jones endekslerinin 1915-1961 aralığındaki trendi ayrıştırılmış aylık değerlerini kullanarak spektrumu incelemişlerdir (Granger ve Morgenstern, 1962: 7-9). Standar\&Poor Endeksi'nin yaklaşık 83 y1llık verisi, borsa ve ekonomiyle ilgili yeterli uzunlukta olup, ABD ekonomisinin 40 aylık konjonktür dalgalanması Şekil 8'de açıkça görülmektedir. Şekil 7'de verilen birinci farkları alınarak düzleştirilmiş Ulusal 100 verisinin spektrumu ile S\&P endeksinde verilen 36 ve 86 uzunluğunda hareketli ortalama (moving average) ile trendi ayrıştırılmış veri, yatay eksenin sol tarafinda bulunan uzun periyotlu (düşük frekanslı) spektrum değerleri dışında benzerlik göstermektedir. Ancak, S\&P endeksinde verilen beş yıllık ve 40 aylık döngüleri spektral analiz tekniğiyle sağlıklı olarak hesaplayabilmek için, verimizin en az 25 yıllık; beş yıllık döngüyü hesaplayabilmek için ise, 35 yıllık olmas1; ayrıca ekonomik sistemin tüm fonksiyonlarının harici ve dâhili şoklardan, ayrıca manipülasyonlardan en az biçimde etkilenebilecek derinliğe sahip olması gereklidir. Ancak, Ulusal 100 endeksinin bu yeterliliğe henüz ulaşamaması nedeniyle, beş yı1lık ve 40 aylı döngüleri tespit edebilmek mümkün değildir. Bunun dışında, bir yılın altındaki döngülerde benzerlikler bulunmaktadır.

$\mathrm{Bu}$ çalışmada, Borsa İstanbul'da görülen bazı dalgalanmaların aslında rastgele dalgalanmalar değil, belli periyotları olan olaylardan oluştuğu tespit edilmiştir. Bu olaylar frekans ortamında incelendiğinden, BİST 100 endeksinin haftalık kapanış verilerinin ne tür bir karakteristiğinin olduğu ve hangi sıklıklarla ve hangi büyüklüklerde azalıp yükseldiği görülmüştür. BİST 100 endeksinde 15 gün, 20 gün, 36 gün, 45 gün ve 60 gün süreli rastgele; 4,5 ay ve 1 y1l süreli mevsimsel ve 2 yıllık konjonktür dalgalanmalar bulunmuştur. Bu dalgalanmalar farklı genliktedir. Yatırımcılar, satın alma veya satma kararı verirken, BİST 100 endeksindeki dalgalanmaların periyotlarını ve genliklerini takip ederek daha verimli kararlar alabilirler. Çünkü, endeks, bu çalışmada elde edilen periyotlarda salınım gösterdiğinden, yatırımcılar endeksin bu çalışmada tespit edilen zaman aralıklarında (periyotlarda) tekrar yükseleceğini veya düşeceğini öngörerek hareket edebilirler.

Frekans düzleminde spektral analiz yapabilmek için, incelenecek zaman serisinin uzun süreli bir seri olmasında yarar vardır. Kısa zaman serileri için zaman düzleminde, zaman serisi analizi daha iyi sonuçlar verecektir. Bu alandaki pek çok çalışmanın 50 yıldan daha fazla veri ile yapıldığını göz önüne alırsak, incelediğimiz BİST Ulusal 100 serisinin 30 yıllık olması nedeniyle, periyodik fonksiyonlar tam olarak belirlenememiştir. Ancak, bu çalışmanın bu alandaki ilk çalışma olması nedeniyle, İstanbul Borsası'nın spektral analiz yöntemiyle daha ileriki yıllarda yapılabilecek olan çalışmalarına temel teşkil edebilmesi açısından önemlidir.

Bu çalışmadan çıkarılacak diğer bir sonuç ise, ülkemizde bu oldukça ihmâl edilen bu konunun geliştirilmesi için, kapsamlı bir çalışma programı yapılmalı ve değişim bilim dallarından oluşturulacak bir grup ile disiplinler arası bir çalışmaya olan ihtiyacın ortaya çıkmasıdır. Spektral analiz konusunun ülkemizde geliştirilmesi özel bir öneme sahiptir. Bu amaçla, üniversitelerin ekonometri bölümlerinde, spektral analiz dersi müfredata alınmalıdır. Spektral analiz dersinin teknik temellerinin iyi kurulması ve matematik bilimine dayanan teorisinin öğrencilere iyi anlatılabilmesi için, hem elektronik, jeoloji gibi hâlihazırda spektral analiz konusunu anlatan diğer disiplinlerden eğitim ve bilgi desteği alınmalı, hem de 
matematik disiplininden spektral analizin teorisi için teorik destek sağlanmalıdır. Ayrıca, istatistik biliminin içine aldığı, tanımlama, yorumlama ve tahmin yöntemlerinin de doğru kurulması için istatistik disipliniyle de işbirliği yapılmalıdır. Bir diğer konu da, elde edilen verilerin işlenmesidir. Spektral analiz, bilişim teknolojilerine dayalı bir yöntem olduğu için, üniversitelerin bilgisayar bölümlerinin de teknik desteği alınmalıdır. En önemli konulardan birisi de, kullanılacak olan yazılımdır. Bu çalışmada kullanılan $\mathrm{R}$ yazılımı, bugün spektral analiz konusunda en kolay uygulama yapılabilecek bir yazılım olduğu ve dünyanın değişik yerlerindeki uzman kişiler tarafından yazılıp paylaşıldığı için, özellikle bu yazılıma önem verilmelidir. Türkiye'deki R grupları hem üniversiteler tarafindan desteklenmeli, hem de üniversitelerin bilgisayar ve yazılım ile ilgili bölümlerinde bu programın öğretilmesi teşvik edilmeli, ayrıca Türkiye şartlarına uygun R kodları ve paketleri geliştirilmelidir.

\section{KAYNAKLAR}

Anders, Philipp (2011), "M310 Time Series and Financial Econometrics-Introduction into Spectral Analysis”, Lecture Note, University of Cambridge, Faculty of Economics, pp.1-14.

Bátorová, Ivana (2012), “Spectral Techniques for Economic Time Series”, Dissertation Thesis, Comenius University Faculty of Mathematics, Physics and Informatics, pp.1215.

Bekçioğlu, Selim (1983), “Menkul Kıymet Analizleri ve Türkiye’deki Uygulama”, Doktora Tezi, Gazi Üniversitesi Sosyal Bilimler Enstitüsü.

Brillinger, David R. (2001), Time Series: General International Encyclopedia of the Social and Behavioral Sciences , Volume 23, Elsevier Ltd., Berkeley.

Charemza, Wojciech W.- Deadman, Derek F. (1997), New Directions in Econometric Practice, Edward Elgar Publishing Ltd., Cheltenham.

Diebold, Francis X. - Senhadji, Abdelhak S. (1996), "Deterministic vs. Stochastic Trend in US GNP, Yet Again." NBER (National Bureau of Economic Research), pp. 3-9.

Diebolt, Claude - Doliger, Cédric (2006), "Economic Cycles under Test: A Spectral Analysis Kondratieff Waves, Warefare and World Security", NATO Security through Science Series E (Derleyen T. C. Devezas), Volume 5, IOS Press, Amsterdam, pp. 39-47.

Enders, Waler (1995), Applied Econometric Time Series, John Wiley and Sons, New York.

Gordon, Robert A. (1961), Business Fluctuations (2nd edition), Harper \& Row, New York.

Granger, Clive W. - Hatanaka, Michio (1964). Spectral Analysis of Economic Time Series, Princeton University Press, Princeton.

Granger, Clive W. - Morgenstern, Oscar (1962), "Spectral Analysis of New York Stock Market Prices”. Princeton University, Econometric Research Program Research Memorandum No 45, pp. 3-9. 
Granger, Clive W. - Watson, Mark W. (1984), Time Series and Spectral Methods in Econometrics - Handbook of Econometrics Volume II, Elsevier Science Publisher BV., Amsterdam.

Gujarati, Damodar N. (2001), Temel Ekonometri, Literatür Yayımcılık, İstanbul.

Hatanaka, Michio. (1965), "A Spectral Analysis of Business Cycle Indicators: Lead-Lag in terms of all Time Point", Research Memorandum No 53, Princeton University, Econometric Research Program, pp.6-15.

Hodrick, Robert J. - Prescott, Edward C. (1997), "Post-War US Business Cycles: An Empirical Investigation", Journal of Money, Credit and Banking, Volume 28, No 4, February, pp. 1-16.

Kazan, Ayşe - Altan, Şenol (2002), "Zaman Serilerin Mevsimsel Etkiler ve En Küçük Kareler Yönteminin Kullanımı", Gazi Üniversitesi İktisadî ve İdarî Bilimler Fakültesi Dergisi, Cilt 4, Sayı 1, ss. 1-10.

Leuthold, Raymond M. (1972), "Random Walk and Price Trends: The Live Cattle Futures Market", Journal of Finance, Volume 27, No 4, September, pp. 879-889.

Mankiw, N. Gregory - Shappiro, Matthew D. (1985), "Trends, Random Walks and Tests of the Permanent Income Hypothesis", Journal of Monetary Economics, Volume 16, No 2, September, pp. 165-174.

McLeod, A. I., Yu, H., \& Mahdi, E. (2012), “Time Series Analysis with R.” Handbook of Statistics, Volume 30, July, ss.661-712.

Nerlove, Marc - Grether, David M. - Carvalho, José L. (1995), Analysis of Economic Time Series. A Synthesis, Academic Press, San Diego.

Öğüt, Kemal Selçuk (1998), "Trafik Akımlarının Spektral Analiz Yöntemi ile Modellenmesi", 4ncü Ulaştırma Kongresi, ss. 147-156.

Özoğuz, Kayıhan (1986), "Zaman Serilerinde Trend Fonksiyon Tipinin Belirlenmesi ve Yorumu", İstanbul Üniversitesi, İktisat Fakültesi Mecmuası, Cilt 42, Say1 1-4, ss. 86.

Parzen, Emanuel (1961), "Mathematical Consideration in the Estimation of Spectra", Technometrics, Volume 3, No 2, pp.167-190.

Venables, William N. - Ripley, Brian D. (2002), Modern Applied Statistics with S (4th edition.), Springer, New York.

Warner, Rebecca M. (1988), Spectral Analysis of Time-Series Data, The Guilford Press, New York.

Wold, Herman O. (1967), "Book Review of Spectral Analysis of Economic Time Series by C. W. J. Granger (in association with M. Hatanaka)", The Annals of Mathematical Statistics, Volume 38, No 1, pp. 288-293. 